PNL-2963

UC-95a

\title{
Preliminary Review of NECPA \\ Generated Information \\ Requirements for the Office \\ of Conservation and Solar \\ Applications
}

R. G. Rivera

A. L. Nieves

March 8, 1979

Prepared for Office of Conservation

and Solar Applications

Department of Energy

under Contract EY-76-C-06-1830

Pacific Northwest Laboratory

Operated for the U.S. Department of Energy

by Battelle Memorial Institute 


\title{
NOTICE
}

This report was prepared as an ac:ount of work sponsored by the United States Covernment. Neither the United States nor the Department of Energy, nur any of their ernployees, nor any of their contractors, subcontractors, or their employees, makes any warranty, uxpress or implied, or assumes any legal liabiity or responsibility for the accurccy, completeness or usafuiness of any information, apparatus, product or process disclosed, or represents that its use would nit iniringe privately owned rights.

The views, opinions and conclusions ccntaised in this refort are those of the contractor and do not necessarily repiesent those of the United States Covernment or the United States Cepartment of Energy.

\author{
PACIFIC NORTHWEST LABORATORY \\ operated by \\ BATTELLE \\ for the \\ UNITED STATES CEPARTMENT OF ENERCYY \\ Under Contract EY-76-C-06-1830
}

\author{
Printed in the United States of America \\ Avaliable from \\ Nitional Technical Information Service \\ United States Department of Commerce \\ S285 Port Royal Road \\ Springfieid, Virginis 2215 ?
}

Price: Printed Copy $\mathbf{5}$ *: Microiriche 53.00

$\begin{array}{cc}\text { - } \text { ages } & \begin{array}{c}\text { NTIS } \\ \text { Selling Price }\end{array} \\ 001-025 & \$ 4.00 \\ 025-050 & \$ 4.50 \\ 051-075 & \$ 5.25 \\ 075-100 & \$ 6.20 \\ 101-125 & \$ 6.50 \\ 126-150 & \$ 7.25 \\ 151-175 & \$ 3.00 \\ 175-200 & 59.00 \\ 261-225 & \$ 9.25 \\ 226-250 & \$ 9.50 \\ 251-275 & \$ 10.75 \\ 275-3100 & \$ 11.00 \\ & \end{array}$


PNL-2963

UC-95a

\section{5}

PRELIMINARY REVIEW OF NECPA GENERATED INFORMATION REQUIREMENTS FOR THE OFFICE OF CONSERVATION AND SOLAR APPLICATIONS

R. G. Rivera
A. L. Nieves

March 8, 1979

Prepared for the U.S. Department of Energy under Contract EY-76-C-06-1830

Pacific Northwest Laboratory

Richland, Washington 99352 


\section{SUMMARY}

Effective implementation of energy conservation policy requires large quantities of various types of good quality, timely data. To obtain the desired data, the information requirements must first be identified so that they can be communicated in a justifiable form to the Energy Information Administration (EIA) and other data collecting organizations.

This report represents the initial results of an effort to describe the general information needed by the Office of Conservation and Solar Applications (CS) to carry out their responsibility in implementing the National Energy Conservation Policy Act (NECPA). The assessment of the NECPA-generated information requirements is organized around the conservation programs for utilities, residences, industry, federal and public buildings and transportation. This assessment identifies the factors that generate the information requirements (sections, parts and titles of NECPA), describes the general information needed to implement the act and references potential sources of data. Appendix $A$ contains a summary of this assessment in table form.

This report is the first in a series in a study to assess the information and data requirements of the Conservation and Solar Office. Subsequent reports will concentrate on specific programs to access detailed data needs. 


\section{CONTENTS}

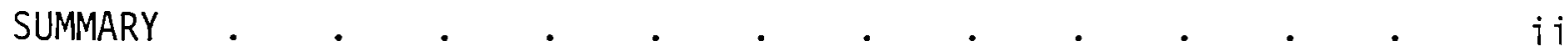

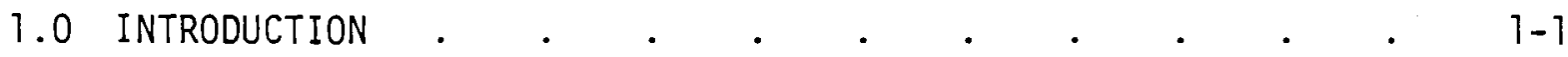

2.0 METHODOLOGY . . . . . . . . . . . . . . . . . .

2.1 INTRODUCTION $. \quad . \quad . \quad . \quad . \quad . \quad . \quad . \quad . \quad 2-1$

2.2 PLAN DESCRIPTION . . . . . . . . . . . 2-2

2.3 STRATEGY . . . . . . . . . . . . . . .

3.0 INFORMATION NEEDS FOR NEA IMPLEMENTATION. . . . . . . $\quad$ - 3-1

3.1 INTRODUCTION $\quad . \quad+\quad . \quad . \quad . \quad . \quad . \quad . \quad . \quad$.

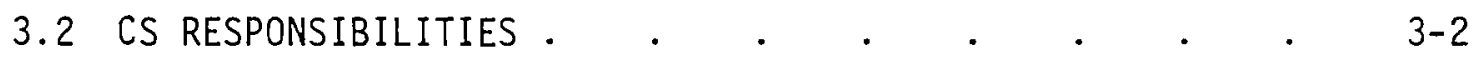

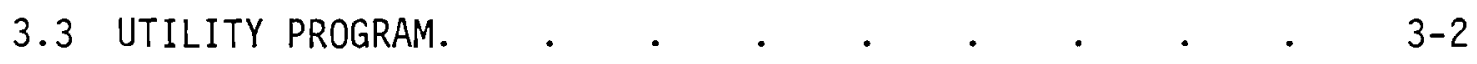

3.3.1 Covered Utilities . . . . . . . . 3-2

3.3.2 Utility Programs . . . . . . . . 3-4

3.3.3 Product Standards . . . . . . . . 3-4

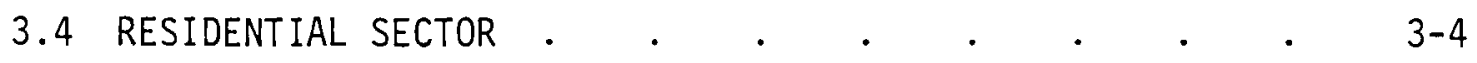

3.4.1 Residential Energy Conservation Plan . . . 3-5

3.4.2 Weatherization Grant Program . . . . . 3-6

3.4.3 Report on Energy Conservation in Apartment . . . . . . . . .
Buildings . . .

3.4.4 Studies on Weatherization and Residential
Energy Efficiency Standards. . . . . 3-7

3.4.5 Procedures for the Residential Energy
Credit. . . . . . . . 3-8

3.4 .6 Other Sections . . . . . . . . . . $3-9$

3.4.7 Information Soruces . . . . . . . . 3-9

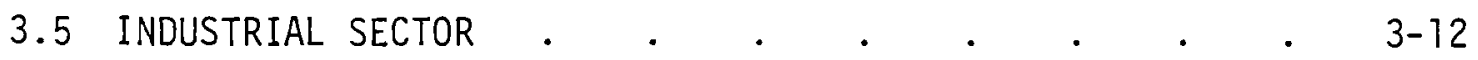

3.5.1 Appliance Energy Efficiency Standards . . . 3-12 
3.5.2 Energy Efficiency of Industrial Equipment . . 3-14

3.5.3 Use of Recovered Materials . . . . . 3-15

3.5.4 Energy Efficiency Reporting . . . . . 3-17

3.5.5 Information Sources . . . . . . . 3-17

3.6 GOVERNMENT AND PUBLIC BUILDINGS . . . . . . . 3-18

3.6.1 Schools and Hospitals . . . . . . 3-18

3.6.2 Units of Local Government and Public Care

Institutions . . . . . . . . 3-19

3.6.3 Federal Solar Program . . . . . . . 3-20

3.6.4 Energy Conservation and Solar Energy in . . 3-20

3.6.5 Federal Photovoltaic Utilization . . . . 3-21

3.7 TRANSPORTATION SECTOR . . . . . . . . . . 3-21

APPENDIX A - SUMMARY OF THE GENERAL INFORMATION NEEDS FOR NEA IMPLEMENTATION $\cdot$.

APPENDIX B - POTENTIAL SOURCES OF ENERGY-RELATED DATA . . . . B-1

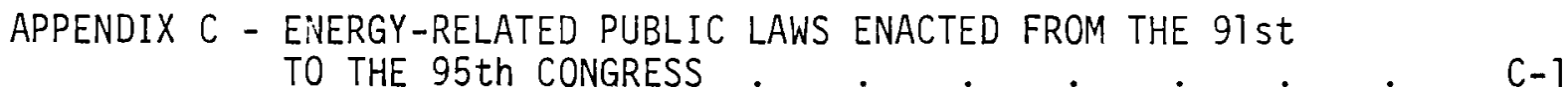




\section{$1.0 \quad$ INTRODUCTION}

The effectiveness of the Conservation and Solar Applications Office (CS) depends, in a large part, on the smooth flow of the information that is needed to carry out its mandate. This requires that the information and data requirements be identified, that good quality data be available and that the data be retrievable efficiently. Constraints in these requirements create special problems in establishing the direction of a program and in managing it. The most recent task in the CS program is the implementation of the National Energy Act (NEA), in particular, the implementation of the National Energy Conservation Policy Act (NECPA).

The purpose of this study is to make a preliminary assessment of the general information requirements for implementing the various provisions of NECPA as it affects the Office of Conservation and Solar Applications. The Act authorizes the making of rules regarding conservation policy that affect the residential, commercial and industrial sectors. It is important that potential impacts on the affected groups be thoroughly understood before these rules are promulgated. The analyses accompanying the development of these rules require extensive data. The assessment of these data requirements and a brief review of potential data sources is the focus of this study.

The Department of Energy Organization Act (PL 95-91) consolidated the responsibility for primary energy data gathering activities in the Energy Information Administration (EIA) of DOE. Due to the diverse nature of the CS program and the historical fact that consumption data by end-use functions has not been systematically collected (such data collection is rather expensive), it is often difficult for users in the CS program divisions and their contractors to identify and obtain reliable data. The identification and access of data is further complicated by the fact that data needed for analysis and decisionmaking is of a type or types (e.g., socioeconomic) that is compiled and maintained in data bases other than those maintained by EIA. (Appendix B contains a summary of potential federal, state and private data sources.) Diversity in location and in methods of data organization make it very difficult to assess the adequacy of data including appropriateness of level of 
aggregation, accuracy and precision, consistency, lack of standardization, and appropriateness of time and frequency of collection.

Throughout this report the following distinction between data and information will be made: data are facts collected from observations or measurements. Information is the meaningful interpretation and correlation of data. In subsequent work, assessments wi11 be made on the detailed data needs generated by a variety of factors and on the adequacy of available data. 


\subsection{METHODOLOGY}

\subsection{INTRODUCTION}

The identification of information requirements is one of the first steps in the process of making decisions. From this step data can be identified, collected, processed and stored so that they are available while still relevant. The incorporation of these activities defines an information system that should be the core of any organization involved in policy-making and implementation. The methodology defined in this section describes one method of identifying the information and data requirements for effective decisionmaking. This method can be used to identify the information needs of the CS office in implementing energy conservation policy including research, development, demonstration and commercialization programs.

Data needs in any organization results from the need to make business or policy decisions. The data needs of the CS office result, primarily, from the need to implement mandates resulting from legislative and executive actions. From these actions a series of events takes place that result in the formulation, implementation and administration of national energy policy. In general, the process takes the following form:

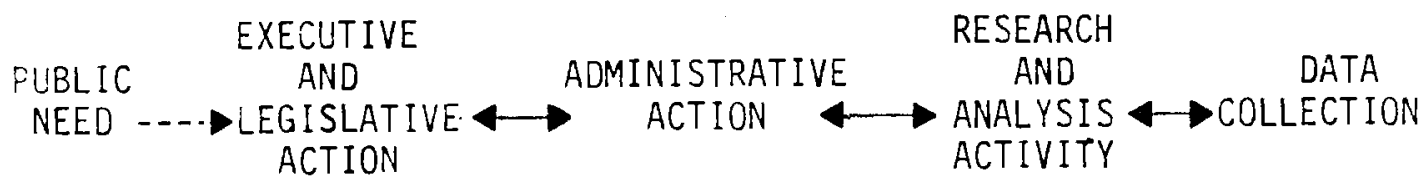

In energy conservation policy, the CS office plays a direct role in the administrative action and indirect roles in the research, analysis and data collection activities. The procedure for assessing information requirements addresses the problem of defining the necessary, information-gathering administrative actions from the Executive and Legislative actions. 


\subsection{PLAN DESCRIPTION}

The procedure for assessing information and data needs of the CS office consists of "filling" a data needs matrix. The data needs matrix consists of an agglomeration of smaller matrices, each having the following dimensions:

1. Factors generating data needs

2. Programmatic functional areas

3. Information - Data types.

The factors generating data needs (factors) consist primarily of Executive, Legislative and Administrative actions. Each factor determines information and data requirements at different levels of abstraction. The factors may be ranked by degree of abstraction as follows:

- laws and policies

- objectives

- regulations

- programs.

Programs are defined as the research, analysis and monitoring activities required to formulate or support regulations. Regulations are the means by which policies and laws are implemented. Laws, policies and objectives generate needs at the same level of abstraction. The objectives may be internally generated by CS and include numerical energy conservation goals and targets.

The second dimension, programmatic functional areas, corresponds approximately to the various CS program offices. These include: Buildings and Community Systems, Industrial Programs, Transportation Programs, Solar Applications, State and Local Programs, Small Scale Technology and Commercialization. Also, each Program Office has a dimension in itself defined by internal areas of responsibility.

The third dimension consists of the information-data types. These may be defined as economic, social, demographic, climatic, technical and other types of information and data requirements generated by a particular factor. Each information-data type is further defined by levels of abstraction which range from more general to more detailed. The most detailed levels would consist of data elements and the most general would consist of information categories. Figure 1 illustrates this concept. 


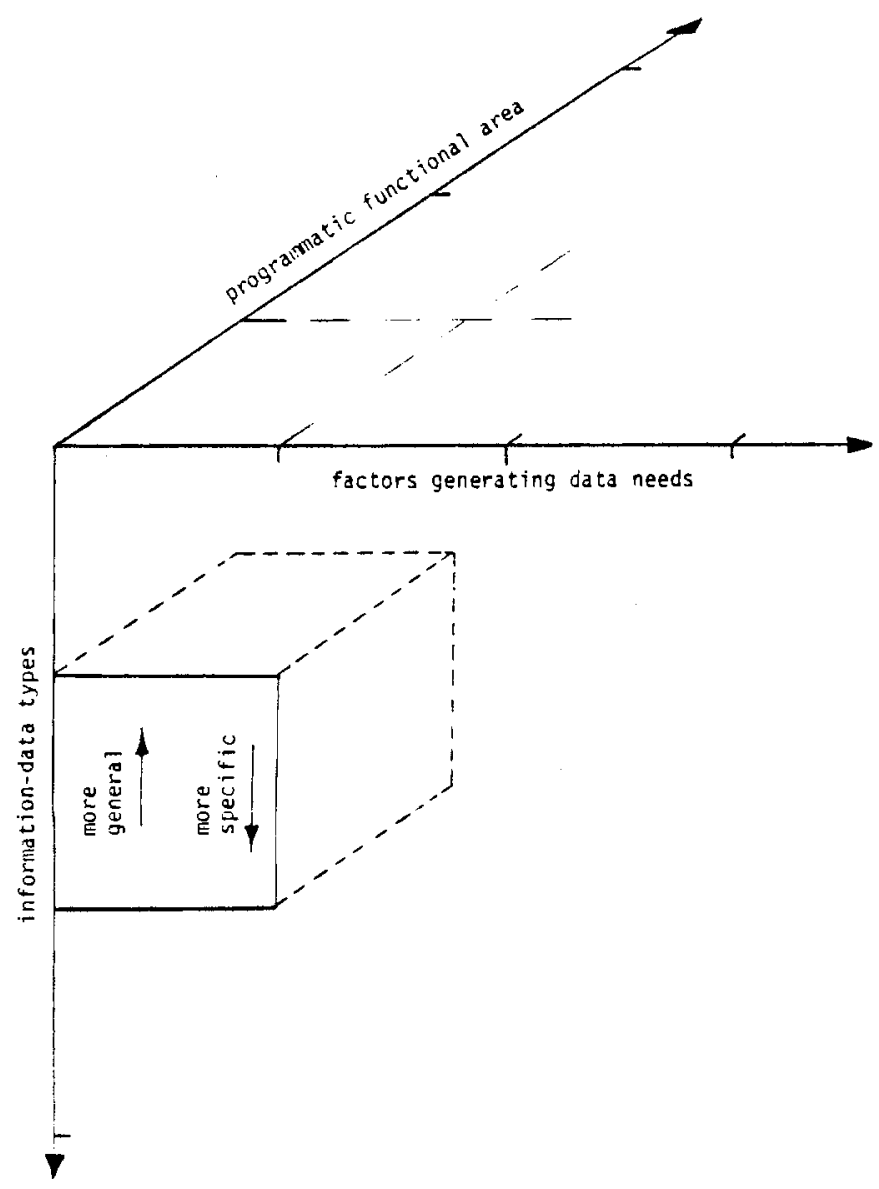

FIGURE 1. Data Needs Matrix

Laws, policies and goals generate information needs which are too general to be used to recommend data collection. Specific data needs are identified and formulated during the research, analysis and monitoring activities necessary for the development of regulations needed to implement the laws. Classifying the data dimension by levels of generality facilitates the investigation of these needs and leads to justified data collection recommendations in a systematic way.

\subsection{STRATEGY}

The development of the data needs matrix can be approached several ways. One is to take "slices" of a plane. Another is to address individual "elements". 
The initial approach taken will be the "slice" approach. We will identify elements in the factors dimension, determine the interaction on the programmatic functional area axis and identify the upper levels of abstraction in the information-data dimension. In other words, we will fill in the top slice of each matrix defined by the factors and the functional area. The second step will be to assess the detailed data needs by individual elements. A method of delimiting the factors that generate data needs is to define logically coherent subsets of the relevant law or policy and proceed toward a preliminary ranking depending on data acquisition priorities determined in concert with relevant CS personnel. The initial subset to be examined is the ilational Energy Conservation Policy Act, NECPA.

The output generated using this plan will be a series of short reports addressing specific factors and organizational interactions with assessments of information needs at different levels of generality. This is the initial report in the series.

Using this kind of structure to analyze data needs has certain advantages. First, different elements of this matrix can be addressed without losing continuity in analysis and reporting. Second, it provides a structure for systematically guiding the analysis as well as for reporting and assessing progress. Third, it is a general approach that can be adapted to any organization. 


\subsection{INFORMATION NEEDS FOR NEA IMPLEMENTATION}

\subsection{INTRODUCTION}

The National Energy Act (NEA) which expands the federal role with respect to energy in the U.S. is the latest in a series of energy-related acts (see Appendix $C$ ) designed to increase energy efficiency. The act is composed of five bills:

- The National Energy Conservation Policy Act (NECPA, PL 95-619)

- The Energy Tax Act (PL 95-618)

- The Natural Gas Policy Act (PL-621)

- The Public Utility Regulatory Policy Act (PL 95-617)

- The Powerplant and Industrial Fuel Use Act (PL 95-620)

By virtue of its mandate, the Conservation and Solar Applications Office of DOE bears primary responsiblity for implementing a significant portion of this law. The act most affecting the CS office is the National Energy Conservation Policy Act. The Energy Tax Act involves some CS resources and coordination with other DOE offices.

This report outlines the information and data requirements implicit in the implementation of NECPA and the Energy Tax Act. In line with the methodology described in the previous section, this report identifies the factors that generate data needs, identifies areas of responsibility and defines the genera 1 information needs for each factor. In effect it addresses the top portion of the data matrix shown in Figure 1. In some cases, however, detailed data needs are explored.

The assessment is organized into the following categories:

- conservation and solar applications office responsibilities

- utility program

- residential sector

- industrial sector

- government and public buildings

- transportation. 
Parts 3.2 through 3.7 provide a detailed assessment of needs in these categories. The information needs for NECPA are summarized in the sequential order of the act in Appendix A.

\subsection{CS RESPONSIBILITIES}

The responsibilities of the Conservation and Solar Applications Office for implementing the NEA are summarized in Table 1. The table shows the interaction of NECPA with the various CS program offices. It identifies the sections for which each office is responsible and identifies some interoffice interactions. In following iterations of this study, specific data needs generating factors will be selected and studied in more detail with respect to organizational responsibility and data needs. The data needs generating factors will be detailed in terms of ongoing and planned research, analysis and monitoring programs generated by both NECPA and the Energy Policy Conservation ACt (EPCA).

\subsection{UTILITY PROGRAM}

Title II, Part 1 of NECPA, the Utility Program, authorizes a utility conservation program for residential buildings. The program requires utilities to offer energy audits to their residential customers that would identify appropriate energy conservation and solar energy measures and estimate their likely costs and savings. Utilities also will be required to offer to arrange for the installation and financing of any such measures. DOE is involved in setting the procedures and standards to guide this program.

\subsubsection{Covered Utilities}

Section 211 of NECPA requires the publication of a list of utilities affected by this law. Although responsibility for its collection may fall outside CS, data are required to identify utilities who sell natural gas (for purposes other than resale) in excess of 10 billion cubic feet per year and utilities who sell electrical energy (for purposes other than resale) in excess of 750 million kis-hours. 


\section{TABLE 1. NEA-CS Interaction Matrix}

Factors

NECPA, Title II, Part 1

Utility Program

NECPA, Title II, Part

Weatherization Grants for the Benefit of

Low Income Families

NECPA, Title II, Part 4

Miscellaneous

NECPA, Title III, Part 1

Conservation Programs for Schools and

Hospitals

NECPA, Title III, Part 2

Conservation Program for Units of Local, Government and Public Care Instutions

NECPA, Title IV, Parts $1 \& 2$

Energy Efficiency Standards for Consumer

Products

NECPA, Title IV, Part 3

Energy Efficiency of Industrial

Equipment

NECPA, Title IV, Part 4

Energy Efficiency by use of Recovered

Materials

NECPA, Title $V$, Parts $1 \& 2$

Demonstration of Solar Heating and Cooling

in Federal Buildings

NECPA, Title, Part 3

Energy Conservation and Solar Energy

in Federal Buildings

NECPA, Title V, Part 4

Federal Photovoltaic Utilization

NECPA, Title VI, Part 1

Industrial Energy Efficiency

Reporting

NECPA, Title VI, Part 2

State Energy Conservation

Plans

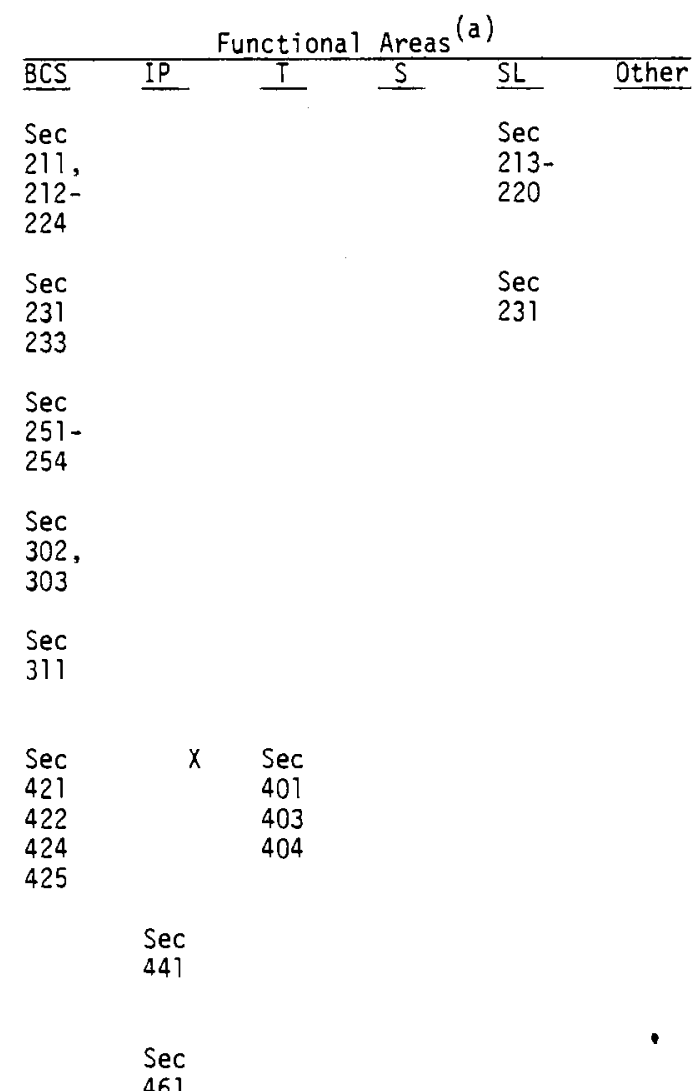

461

$\begin{array}{ll} & \text { Sec } \\ \text { Sec } & 521 \\ 501 & 522 \\ & 523\end{array}$

Sec
545
546
547

$x^{(t)}$

$x$
Sec

566
567

Sec
601

$\mathrm{Sec}$
521
522
523

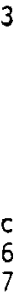

Sec

621

622

(a) The following CS offices make up the functional areas; Building and Community Systems, Industrial Programs, Transportation Programs, Solar Applications and State and Local Programs. Other offices include Small Scale Technologies, Commercialization and Policy Planning and Evaluation.

(b) Secondary responsibility for this part of the law. 


\subsubsection{Utility Programs}

Sections 213 through 220 of NECPA authorize the implementation of the residential energy conservation plan through states and utilities. The NECPA requires that a utility must inspect the customer's residence upon request to determine which conservation and solar energy measures would be cost effective. The utility must also provide lists of lenders, suppliers and contractors and offer to arrange for the installation or financing of conservation and solar measures by listed firms. Except in certain cases, utilities are prohibited from directly installing such materials or actually making loans. One exception is that utilities may install furnace modifications and thermostats if customers desire.

CS has a responsibility in the development of guidelines for implementing this program. These data needs will be outlined in Section 3.4 .1 of this report.

\subsubsection{Product Standards.}

Section 222 of NECPA authorizes the setting of standards on products or materials for judging the efficacy, energy efficiency, safety or other attributes of energy conservation materials, products or devices. Although DOE is responsible for these standards, they will actually be developed by the National Bureau of Standards under contract to DOE.

\subsection{RESIDENTIAL SECTOR}

Authority in the residential sector is given by Title II of NECPA and indirectly by Title I of the Energy Tax Act. The responsibilities are 1) making the rules prescribing the content and implementation of the residential energy conservation plan, 2) determining the standards and guidelines for the weatherization grant program, 3) reporting on energy conservation in apartment buildings, 4) studying weatherization and residential energy efficiency standards, and 5) assisting in establishing the criteria and certification procedures for the residential energy credit. 


\subsubsection{Residential Energy Conservation Plan}

Section 212 of NECPA provides authority for making rules prescribing the content and implementation of residential energy conservation plans. These plans will provide the guidelines for energy audits by utilities and for the weatherization programs. The rules should include standards on safety, efficiency, prices, interest rates and business practices.

The information requirements for developing these rules are extensive and at a level of complexity comparable to those for the development of new building energy performance standards (BEPS). Some of the information obtained for (and results from) the BEPS program may be transferable and used in developing these rules. However, there are some major differences that will require additional information.

Information is needed to establish a baseline on housing characteristics. Data are needed to characterize residences by structure type, age, size, orientation, climatic region and demographic data including community size, housing patterns, etc. Information is also needed to determine the economic and environmental impacts of these plans, that is, the impacts on homeowners, utilities, suppliers of materials for modification and retrofitting and on lending institutions. Models such as that used by ORNL (described later) are an important source for this kind of information.

Data are needed to determine the life cycle costs of homes. This need requires both economic and technical data on the thermal efficiency of homes, effects of weatherization, amounts of energy used, cost of materials, and most importantly the expected costs of energy.

Improvements in thermal efficiency will have secondary effects on the home environment (e.g., air circulation). There are many toxic substances whose vapors can accumulate to dangerous levels without proper ventilation. Data is needed to determine the type, quantity and characteristics of these toxic substances and, in general, to establish a baseline on human environmental needs in a home. 
Section 220 of Title II does not supersede any law or regulation of any state or political subdivision of a state. Data are needed to identify the legal and financial barriers to implementing the Residential Energy Conservation plan if any, and to develop means to overcome them.

\subsubsection{Weatherization Grant Program}

The program for Weatherization Grants for the Benefit of Low Income FamiTies is described by Part 2 of Title II of NECPA, Residential Energy Conservation. The responsibility of the CS office is defined by Section 231, DOE Weatherization Grant Program and, indirectly, by Section 233, Availability of Labor. Section 231 is an amendment to Section 412 of the Energy Conservation in Existing Buildings Act of 1976. It prescribes the writing of standards to be applied to each dwelling unit to determine cost-effective measures to achieve optimum savings of energy.

Information needs generated by these sections involve the determination of:

- the effects of weatherization material

- caulking and weatherstripping

- furnace efficiency modification

- ceiling, attic, wall, floor, and duct insulation

- water heating insulation

- storm windows and doors

- heat-absorbing or heat-reflective materials

- the effects of improved technology on space conditioners

- the effects of variation in climate and climatic regions

- the value of energy saved by the application of the weatherization material.

The responsibility of Section 233, Availability of Labor, falls on DOE. However, responsibility for the information and resources to carry out this task lies with the Community Services Administration and the Department of Labor. To carry out this responsibility information is needed to: 
- determine the number of individuals needed to supply sufficient labor to carry out the weatherization program

- identify the areas of the country where there is an insufficient number of volunteers, training participants and public service employment workers to carry out the weatherization program

- insure that the weatherization programs are supported to the maximum extent practicable in such areas by volunteers and training participants and public service employment workers.

\subsubsection{Report on Energy Conservation in Apartment Buildings}

Section 224 of NECPA calls for the preparation of a report on the potential for energy conservation in apartment buildings. Information is required to determine the conservation effects of structural and energy control measures, and an application of a utility program to apartment buildings. Information is also needed to determine the cost of achieved energy conservation, and the need for federal financial assistance.

The data needs for this report are similar to the needs of the residential energy plan and the weatherization grant program. Although the report is due before data can be identified and collected, legislation resulting from this report may require it.

The information for this report may best be generated through models. Typical data needs for these models are outlined in Section 3.4.7.1.

\subsubsection{Studies on Weatherization and Residential Energy Efficiency Standards}

Sections 253 and 254 of NECPA require that studies be made on residential energy efficiency standards and on the weatherization programs. The authority for the efficiency standards study is placed with HUD. For the weatherization study, authority rests with the President. DOE is responsible for consulting and being a resource for these studies.

The Residential Energy Efficiency Standards Study should determine the need for, the feasibility of, and the problems of requiring, by mandatory federal action, that all residential dwelling units meet applicable energy efficiency standards. Information is needed to determine the impacts of these standards on: 
- real estate, home building and mortgage and banking industries

- sellers and purchasers

- national energy conservation goals

- the national economy

- national security

- voluntary energy conservation efforts.

Information is also needed to:

- determine the energy savings due to conservation efforts

- determine the legal effects of standards on home buyers

- determine the barriers and incentives for implementation of standards.

The weatherization study (Section 254) requires monitoring weatherization activities authorized by NECPA and other acts. Information is needed to determine the:

- adequacy and costs of materials

- effects on different income groups and utilities

- status of energy conservation goals

- need and desirability of modifying the weatherization program.

\subsubsection{Procedures for the Residential Energy Credit}

Section 101 of the Energy Tax Act authorizes the development of criteria to be used in prescribing performance and quality standards on insulation, energy-conserving components and renewable energy source property. Primary responsibility lies with the Department of the Treasury; however, DOE has consulting responsibilities in establishing these criteria. The information needs generated by this section include:

- information on the type, quality, efficiency and cost of insulation designed for dwellings and pipes

- information on the type, quality, efficiency and costs of components used in energy conservation. These may include furnace burners, devices for modifying flue openings, electrical or mechanical furnace ignition systems, storm or thermal window or doors, thermostats, caulking or weatherstripping, energy usage meters and any other item which might increase energy efficiency. 
- information dealing with the technical, environmental and efficiency characteristics of energy derived from geothermal deposits, wind and other energy sources used for nonbusiness residential purposes.

\subsubsection{Other Sections}

There are other sections in NECPA where the CS office is not directly affected but where it may be called on as a source of residential information. Among these are Section 251, "Energy-Conserving Improvements for Assisted Housing"; Section 252 "Energy Conserving Standards for Newly Constructed Residential Housing Insured by Federal Housing Administration or Assisted by Farmers Home Administration"; Section 232 "Farmers Home Administration Weatherization Grant Program"; and others. The data needs of these other sections are similar to those described in Sections 3.4.1 through Section 3.4.5 of this report.

\subsubsection{Information Sources}

The data available to address these needs are not always adequate. Government residential data relevant to conservation policy generally come from models (such as the ORNL Engineering-Economic Model of Residential Energy Use) and through surveys conducted by the Department of Commerce. Data bases exist in other private or public organizations such as The National Association of Home Builders, University of Wisconsin, the Rand Corporation, etc. The Residential Energy Consumption Survey being conducted by the Energy Information Administration will be a useful source of residential energy consumption data. Information is being collected on energy consumption in personal transportation, space conditioning and applicances. However, no data source in itself is completely adequate since each is oriented to a specific need. The following sections describe some relevant data sources and their drawbacks.

3.4.7.1 The ORNL Engineering-Economic Model of Residential Energy Use

This model was developed to simulate energy use in the residential sector from 1970 through the year 2000. The model provides information on annual energy uses by fuel, end use, and housing type, and also estimates annual 
equipment installation and ownership, equipment energy requirements, structure thermal performance, fuel expenditures, equipment costs and costs for improving thermal performance of new and existing housing units.

A key factor in this model is the use of price, cross price and income elasticities to arrive at its output. Factors considered in the assessment of elasticities on substitution and consumption include overal1 fue 1 use, equipment fuel choice, equipment usage, and technical efficiency. The data to estimate (or infer) these parameters come from a variety of sources. Among these are:

- Bureau of Mines

- Nationar Oceanic and Atmospheric Administration

- Environmental Science Services Administration

- Edison Electric Institute

- Annual Housing Survey, Bureau of Census

- United States Department of Agriculture

- Survey of Current Business, Bureau of Census

- Rand Corporation

- American Gas Association

Data from these sources are inadequate to estimate the desired elasticities; this is an aspect of the model's use requiring improvements. Better data are needed in the following areas:

- fuel consumption

- fuer prices

- fuel availability

- equipment costs

- utilization of equipment

- operating costs

- capital costs

- discount rates

- equipment lifetimes

- lifecycle costs. 
The data needs outlined above are an aggregated summary of the overa 11 data needs for this type of model. Detailed technical and economic data are needed to develop such information as discount rates, lifecycle costs, equipment costs, etc.

\subsubsection{Data Bases}

There are a variety of data bases available relevant to needs generated by NECPA, some of these were mentioned in the previous section. Some problems associated with this data are:

- lack of standardization

- inappropriate level of aggregation

- inappropriate time or frequency of coliection

- inadequacy in quantity and detail

- inconsistency in sample population.

Moreover, they are difficult to identify and retrieve.

There are several sources of data that have significant value. Among these are The National Association of Home Builders (of whose data the BEPS program makes significant use), the Bureau of the Census and EIA. The most current data will be available through EIA from the Residential Energy Consumption Survey. The survey is now being implemented and data should be available this year. The data will cover residential energy consumption relating the social and economic characteristics of residents to energy consumption in personal transportation, space conditioning and appliances. It also provides data on structural characteristics and thermal characteristics of homes.

The data from The National Association of Home Builders and the Annual Housing Survey covers a period of years and is useful time series data. The Annual Housing Survey has a section on energy conservation. It is not as extensive as EIA's Residential Energy Consumption Survey, but does provide some information on weatherization and space conditioning characteristics.

A good general source on residential data is the Buildings Energy Use Data Book prepared by ORNL. The book presents a large amount of relevant data on current and past energy and use activities in the residential and commercial 
sector. The indexing matrix being developed for Edition 2 of the Buildings Data Book will provide one way of identifying data gaps.

A summary of potential data sources is outlined in Appendix B.

\subsection{INDUSTRIAL SECTOR}

The needs for data in the industrial sector are generated primarily by Title IV of NECPA. It provides authority to 1) develop energy efficiency standards for appliances, 2) improve energy efficiency of industrial equipment, 3) develop targets, create procedures and provide incentives for increased industrial utilization of energy saving recovered materials, 4) report on industrial energy efficiency, and 5) study barriers to implementation. This section of the law is an amendment to section 323 of EPCA.

Because of its proprietary nature, it may be difficult to obtain some of the needed industrial data. The possibility of this information becoming public knowledge might discourage its disclosure. Information such as use characteristics of industrial equipment and estimates of current and future equipment stock profiles could be considered business sensitive. Although the law authorizes the collection of this information, (NECPA Section 425), it may be difficult to obtain at low enough levels of aggregation for effective implementation of this law.

\subsubsection{Appliance Energy Efficiency Standards}

Section 422 of the National Energy Conservation Policy Act, an amendment to Section 325 of EPCA, authorizes the rulemaking on energy efficiency standards for the following products:

- refrigerators and refrigerator-freezers

- freezers

- dishwashers

- clothes dryers

- water heaters

- room conditioners
- home heating equipment, (not including furnaces)

- television sets

- kitchen ranges and ovens

- clothes washers

- humidifiers and dehumidifiers

- central air conditioners

- furnaces. 
In addition, DOE has made a tentative determination to include heat pumps as a class of central air conditioners.

An energy efficiency standard is defined as a performance standard (as opposed to a design standard) which prescribes a minimum energy efficiency level for each unit of a covered product. The standards include test procedures and any other requirements to ensure compliance.

In the Advance Notice of Proposed Rulemaking, DOE identifies seven factors to consider in devising these standards:

- impact on manufacturers and consumers

- savings in operating costs throughout the estimated average Iife of a product

- total projected amount of energy savings likely to result from the imposition of the standard

- any lessening of the utility or the performance of the product likely to result from the imposition of the standard

- the impacts of any lessening of competition

- the need of the nation to conserve energy (estimated National Energy Savings)

- other factors such as impact on suppliers, distribution and retailers of component parts.

The Office of Consumer Products in the Office of Buildings and Community Systems (BCS) has compiled an extensive list of technical and economic data requirements on products and industry. (SRI International organized and summarized these data requirements under DOE Contract No. EY-76-6-03-0115). The emphasis of this effort is to identify the data needed from industry for determining appliance energy efficiency standards. This data needs assessment was made on some of the covered products and on industry.

The economic data needs covered in the Office of Consumer Products summary are those needed to help assess the present and projected impacts of appliance standards on a company's:

- financial structure

- cost structure

- manufacturing structure

- sales and marketing. 
The technical data needs covered in the Office of Consumer Products summary include the performance characteristics, design data and technical specifications for the following products:

- air conditioners

- water heaters

- refrigerators

- freezers

- refrigerator-freezers
- clothes washer

- dishwashers

- clothes dryers

- kitchen ovens

- kitchen ranges

\subsubsection{Energy Efficiency of Industrial Equipment}

Section 441 of NECPA calls for improved energy efficiency of industrial equipment. The law provides authority for, 1) evaluating industrial equipment, 2) setting test procedures for classes of equipment, and 3) labeling equipment. The types of equipment affected are:

1. electric motors

2. pumps

3. compressors

4. fans

5. blowers

6. refrigeration equipment

7. air conditioning equipment

8. electric lights
9. electrolytic equipment

10. electric arc equipment

11. steam boilers

12. ovens

13. furnaces

14. kilns

15. evaporators

16. dryers.

The evaluation of industrial equipment will culminate in a report to Congress detailing the results of the evaluation and recommending appropriate legislation. This evaluation will require data for a variety of studies. For example, data are needed to:

- characterize equipment and general usage within equipment types

- determine standard classifications with respect to size, function, type of energy used and other appropriate factors

- determine the practicability and impacts of requiring equipment to meet performance standards

- identify significant factors that determine energy efficiency 
- estimate current and future equipment population profiles

- estimate the potential for technologically feasible and economically justified improvements in energy efficiency

- estimate total energy savings (if any) resulting from the standards The number of industries is so large and the operations and products are so diversified that information may best be generated through models. Models such as the Industrial Sector Technology Use Model (ISTUM) from Energy and Evaluation Analysis, Inc. and others generate some of the desired information. Obtaining a useful level of aggregation in terms of region, industry and process type is sometimes problematic. The Standard Industrial Classification (SIC) provides one framework for describing the industrial sector. It may be more useful; however, to break down data needs by the types of processes that describe different industries:

1. processes that change the molecular structure of materials

2. processes that change the configuration of materials

3. processes that change the physical arrangement or location of materials.

Industries in different categories are more intensive in the use of different industrial equipment. For example, industries in the second and third categories might be more intensive in the use of equipment types three through eight and industries in the third category might be more intensive in the use of equipment types nine through sixteen.

Data are also needed to characterize the decision-making behavior of industries. This requires economic data for estimating the demand for industrial products, the cross fuel elasticities of substitution, etc. The data needs are similar to the industrial data described for the appliance energy efficiency standards.

\subsubsection{Use of Recovered Materials}

The development of targets, procedures and incentives for increased industrial utilization of energy saving recovered materials is authorized by Section 461 of NECPA. This is an amendment to ECPA Section 374 and is oriented 
to the metals and metal products, paper and allied products, textile mill products, and rubber industries.

The materials covered are those recovered from solid waste, as defined in the Solid Waste Disposal Act, and include: aluminum, copper, lead, zinc, iron, steel, paper and allied products, textiles and rubber. There is a need for baseline information on the recovery of these materials. This requires data to identify industries that are recovering or could recover materials, how these recovered materials are being used, their quality before and after processing and the cost and energy required to recover them. Information is also needed to estimate present and projected demand and supply for these products and their feasible recovery rates.

Creating the procedures whereby industries may cooperate in establishing and achieving the targets requires little data collection. Providing incentives, on the other hand, will require assessing the economic impacts on different size industries and on fair competition. This will require information on the technologies used and on the adaptability of new technologies for materials recovery.

The law requires that targets be established on energy-saving recovered materials for each of the identified industries at levels that represent the maximum feasible increase in utilization. It also mandates that the standards must be within the technological and economic ability of an industry to reach them by January 1, 1987. This will require both technical and economic data on affected industries. Data are needed to:

- identify significant factors that determine energy efficiency

- determine the criteria for technological and economic feasibility

- estimate the potential energy savings from the utilization of recovered materials.

Industry, as a cooperative partner in the establishment of these targets, will submit recommendations on what these targets should be. To evaluate these proposals data is needed to understand the factors guiding industrial decision-making. Data on the technical factors of material recovery, the industrial manufacturing structure, and the industry cost structure would be useful for understanding their activity. 


\subsubsection{Energy Efficiency Reporting}

Section 601 of NECPA requires that an annual report be submitted to Congress on the industrial energy efficiency program. (This program is authorized by ECPA Section 372). The report should include a summary of the progress made in meeting efficiency targets and recommendations to Congress on how additional improvements might be achieved. The law also authorizes DOE to request reports from corporations on the progress each corporation has made in improving its energy efficiency. It also authorizes the development of forms for obtaining the information needed from corporations. However, the law specifies that forms be designed in a manner to avoid imposing an undue burden on corporations.

Information is needed to identify and classify industries by the amount of energy consumed (authorized by ECPA, Section 374), and to set targets representing the maximum feasible improvement in energy efficiency. Data are also needed on the amount of energy consumed, the type of energy consumed and the classification of its consumption.

\subsubsection{Information Sources}

Data that describe industrial energy vary widely in scope and availability. Some data, in the form of internal management information, are available from individual firms, or from trade associations. One source of industrial energyuse data is the quinquennial Census of Manufacturers and the Annual Survey of Manufacturers from the Department of Commerce. These data include amounts of fuel and electric energy consumed for heat and power by manufacturing industries. Purchased fuels and electricity consumed by the mineral industries are also reported by the Department of Commerce at five-year intervals.

Other federal sources of industrial energy consumption are: (a)

- the Bureau of Mines' annual survey of petroleum distributors and medium to large retailers

- the Federal Reserve Board's monthly survey of industrial electric power use

(a) Some of this data may be incorporated in EIA's data bases. 
- the Federal Energy Regulatory Commission's monthly data on fuels used by electric power utilities.

An important source of industrial energy consumption data is the Energy Information Administration. Extensive data files are maintained and the Information Element Dictionary, IED, (being developed) will facilitate the identification and access of industrial energy information.

Two other developments are worth indicating at this time. One is the industrial survey being developed by EIA. It is in the preliminary planning stages and will not be implemented for two years. The other is an effort by ORNL to develop an Industrial Data Book. This too is in a preliminary stage of development, but when completed should provide information in a manner similar to the Transportation and Buildings data books.

A summary of potential data sources is outlined in Appendix B.

\subsection{GOVERNMENT AND PUBLIC BUILDINGS}

In the government and public buildings sector, two titles of PL 95-619 principally apply. Title III delineates conservation programs funded by grants to states and public and nonprofit schools and hospitals to implement conservation measures in schools, hospitals, buildings owned by units of local governments and public care institutions. Title V, Federal Energy Initiative, details conservation measures and demonstration of alternative technologies to be implemented in federal buildings.

\subsubsection{Schools and Hospitals}

Schools and hospitals are major consumers of energy, but substantial conservation is achievable through implementation of energy conservation measures. It is recognized that public and nonprofit schools and hospitals may often require financial assistance to accomplish such goals. This part of the act authorizes grants to assist in identifying and implementing conservation measures.

Also in Part 1 , the Secretary is required to establish guidelines for conducting preliminary energy audits and energy audits. In addition, the Secretary is required to establish guidelines for state plans for implementation 
of energy conservation projects in schools and hospitals. Inherent in the establishing of such guidelines is a need for data/information concerning factors that may be involved in grant decisions. Among such factors are: cost, energy consumption, energy savings and energy conservation goals. Some variation between regions exists and regional appropriateness must be detailed. It is apparent that the level of disaggregation necessary is at least regional.

Also required by this part is a statement of the criteria for determining severe hardships. Such determination necessitates information concerning:

- climate

- fuel costs

- fuel availability

- ability to provide non-federal share of costs and such other factors as the Secretary may deem appropriate.

\subsubsection{Units of Local Government and Public Care Institutions}

Part 2 of Title III pertains to units of local government and public care institutions. For purposes of this part the term "unit of local government" means the government of a county, municipality, or township, which is a unit of general purpose government below the State (determined on the basis of the same principles as are used by the Bureau of the Census for general statistical purposes) and the District of Columbia. This term also means the recognized governing body of an Indian tribe (as defined in Section 412 of the Energy Conservation and Production Act) which governing body performs substantial governmental functions. A public care institution, on the other hand, is defined as a public or nonprofit institution which owns a) a facility for long term care, a rehabilitation facility, or a public health center, as described in Section 1633 of the Public Health Service Act, or b) a residential child care center.

The reporting requirements for both parts 1 and 2 of Title III require that the Secretary submit a detailed report of the actions taken or planned under the provisions of these parts. Among the requirements are two with present and future data/information requirements. These involve: 
- information on the types of conservation measures implemented

- an estimate of the energy savings achieved.

Inherent in any assessment of achieved savings is a requirement for baseline data on present consumption levels.

\subsubsection{Federal Solar Program}

Title $V$ of NECPA deals with conservation measures and alternative technologies in federal buildings. Part 2 delineates the requirements of the Federal Solar Program to demonstrate the application of solar heating and solar heating and cooling technology in federal buildings. This part requires that the Secretary establish requirements and criteria for the submission and evaluation of proposals for the installation of solar energy equipment in federal buildings.

Among the requirements generating potential data/information needs are those calling for a complete analysis of the present value, as determined by the Secretary, of the costs and benefits of the proposal to the federal agency, and for the demonstration, to the maximum extent practicable, of innovative and diverse applications in a variety of types of federal buildings of solar heating and solar heating and cooling technology. It further calls for location of demonstration projects in areas where a private sector market for solar energy equipment is likely to develop. Also in conjunction with Part 2 are requirements for 1 ife-cycle cost analysis and reports to the Secretary when such solar energy equipment is not the minimum life-cycle cost alternative. Such reports would state the amount by which the life-cycle cost of equipment exceeds the minimum.

\subsubsection{Energy Conservation and Solar Energy in Federal Buildings}

Part 3, dealing with energy conservation and solar energy in federal buildings, recognizes that the Federal government should be in the forefront in implementing energy conservation measures and promoting the use of renewable energy sources. It also recognizes that in the construction or rennovation of buildings, the cost of energy consumed in such buildings must be considered in addition to the initial cost of such construction. It is stipulated that all federal buildings be life-cycle cost-effective and that cost evaluation shall be made on the basis of life-cycle rather than initial cost. 


\subsubsection{Federal Photovoltaic Utilization}

Part 4 of Title $V$ deals with federal photovoltaic utilization and establishes a photovoltaic energy commercialization program to speed procurement and installation of photovaltaic systems for electricity production in federal facilities.

As a consequence of Part 4 the Secretary is required to prescribe rules and regulation to monitor and assess the performance and operation of photovoltaic electric systems. Implicit in this requirement is a need for data/ information regarding costs, operating and performance characteristics of such systems.

\subsection{TRANSPORTATION SECTOR}

Title IV of NECPA deals with energy efficiency of certain products and processes. Part 1 pertains to energy efficiency standards for automobiles stipulating guidelines for civil penalties relating to automobile fuel efficiency. This part further requires that the Environmental Protection Agency, in consultation with the Secretaries of Energy and Transportation, report to Congress providing a realistic estimate of average fuel economy likely to be achieved.

It is probable that the Transportation and Energy Conservation Office of CS will bear responsibility for such collaborative efforts necessitated by this part of the act.

Title II of the Energy Tax Act of 1978 (PL 95-618) is titled Transportation and contains the following parts:

Part I - Gas Guzzler Tax

Part II - Motor Fuels

Part III - Provisions Related for Buses

Part IV - Incentives for Van Pooling

Primary responsibility under Title II of this act lies with the Secretary of the Treasury and the administration of the Environmental Protection Act. Potential for consultation with various DOE components does exist, however, and in some cases is explicit in the provisions of the act. 
Required or potentially required data/information needs include the following:

Part I: Fuel economy - Smal1 Manufacturers and special rules.

Part II: Alcohol fuel industry - firms engaged in such production Alcohol fuels - quantity sold by state

Revenue losses resulting from alcohol fuel tax exemption Production costs for alcohol fuels

Retail costs of alcohol fuels compared to gasoline and special fuels before Federal excise tax

Part III: There are no explict reporting requirements in Part III (provisions related to buses). In areas such as inventory characteristics, stocks, fuel efficiency it is conceivable that the Secretary of the Treasury may rely on either DOE or DOT for information.

Part IV: This part contains no explicit requirements. Comments directly above are applicable. 
APPENDIX A

SUMMARY OF GENERAL INFORMATION

NEEDS FOR NEA IMPLEMENTATION 
LAW: NECPA

TITLE: II - Residential Energy Conservatiun

PART : $\quad 1-$ Utility Prograil

\begin{tabular}{|c|c|c|c|c|}
\hline $\begin{array}{l}\text { ACT } \\
\text { SECTION }\end{array}$ & DESCRIPTION & GENERAL INFORMATIUNN NEEUS & $\begin{array}{l}\text { ArFECIIU } \\
\text { OFFICE }\end{array}$ & POTENTIAL DATA SOURCES \\
\hline 212 & $\begin{array}{l}\text { Rules prescribing the content and } \\
\text { iuplemeritation of residential energy } \\
\text { conservation plans }\end{array}$ & $\begin{array}{l}\text { Major categories of information needs: } \\
\text {-Economic. Inpacts on hone inners, } \\
\text { business and industry. } \\
\text { - Demographic. Social, economic and } \\
\text { geographical profiles of residents } \\
\text {-Envirommental. Basic human needs, } \\
\text { vis-a-vis home environment (c.s., air } \\
\text { circulation) } \\
\text { - Climatic. Reyional characteristics } \\
\text { - Building. Stock } \\
\text {-Structural. Characteristics of res- } \\
\text { idential buildings } \\
\text {-Financial and Legal. Building } \\
\text { codes, etc. }\end{array}$ & BCS & 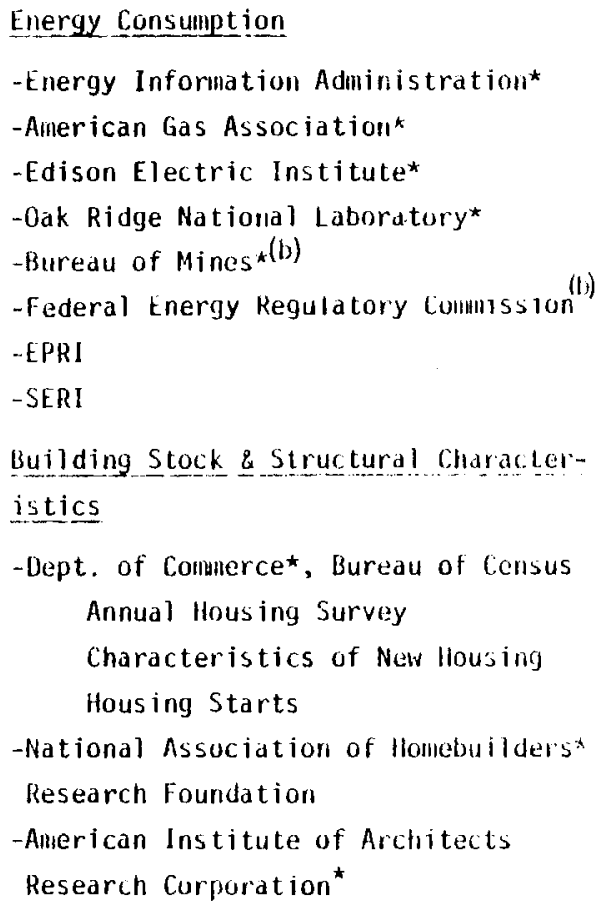 \\
\hline
\end{tabular}

(b) Some data from the Bureau of Mines and the Federal Power Cummission are now in ElA data bases. 


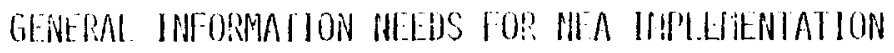

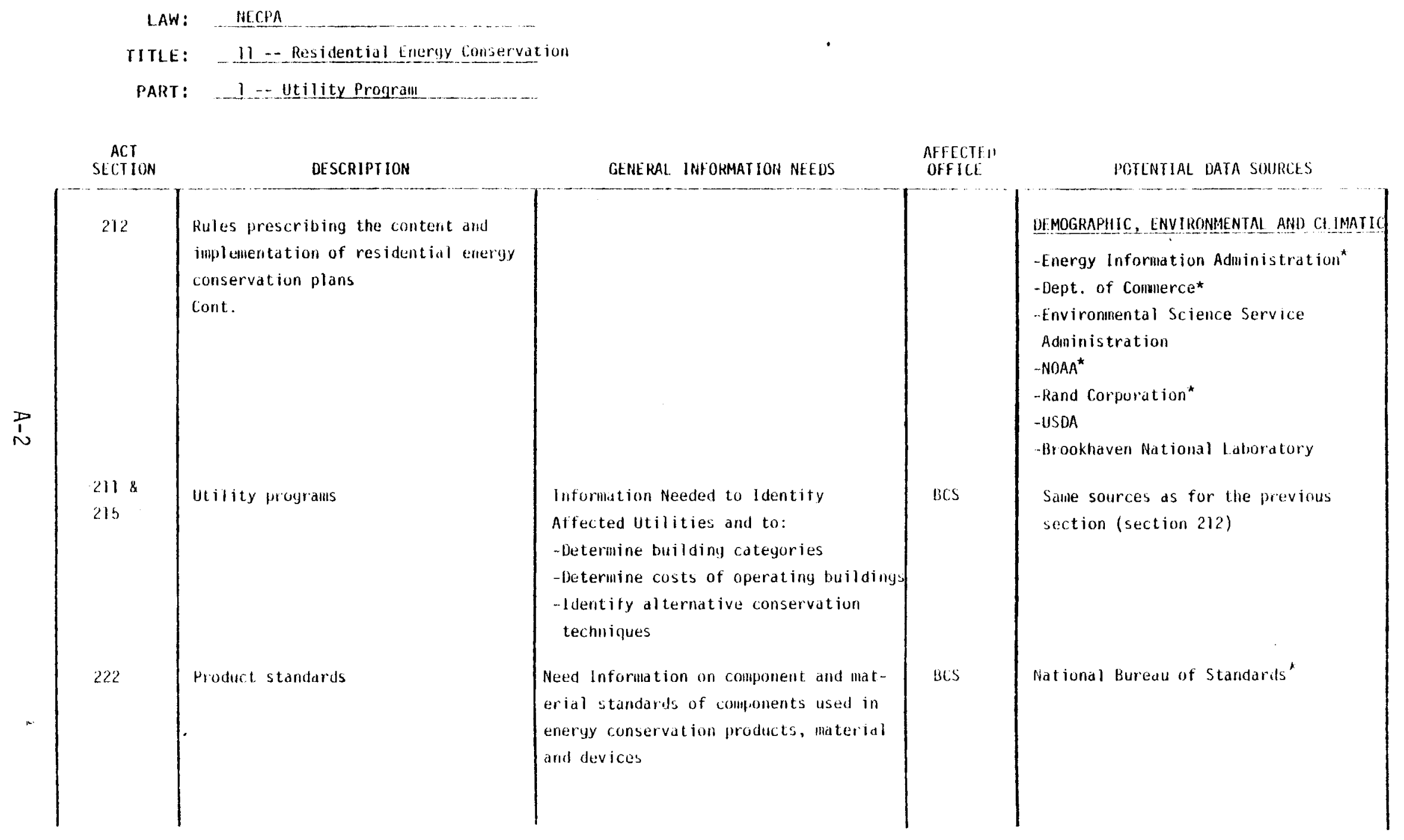

* Gata suurce used in Builaings data book 


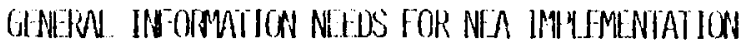

LAW: NECPA

TITLE: $\quad 11$ - Residential Energy Cunservatiun

PART : $\quad 1$-... lltility Program

\begin{tabular}{|c|c|c|c|c|}
\hline $\begin{array}{c}\text { ACT } \\
\text { SECTION }\end{array}$ & DESCRIPTION & LENEPAL INFORMATION NEEOSS & $\begin{array}{l}\text { AFFECTLD } \\
\text { OFFICE }\end{array}$ & POTENTIAL DATA SOURCES \\
\hline 224 & $\begin{array}{l}\text { Report on energy conservation in } \\
\text { apartment buildings }\end{array}$ & $\begin{array}{l}\text { Need Information on component and mat- } \\
\text { erial standards of components used in } \\
\text { energy conservation products, material } \\
\text { and devices } \\
\text { Need irformation: } \\
\text {-On energy consumption } \\
\text { - To describe the type, quantity, use } \\
\text { and occupancy of apartnerits } \\
\text {-To establish a baseline on energy use } \\
\text {-To identify the type of retrofits and } \\
\text { increases in ellergy efficiency } \\
\text {-0n costs of retrofits (baseline) } \\
\text {-0n economic claracteristics of dwell- } \\
\text { ing owners }\end{array}$ & $\mathrm{BCS}$ & 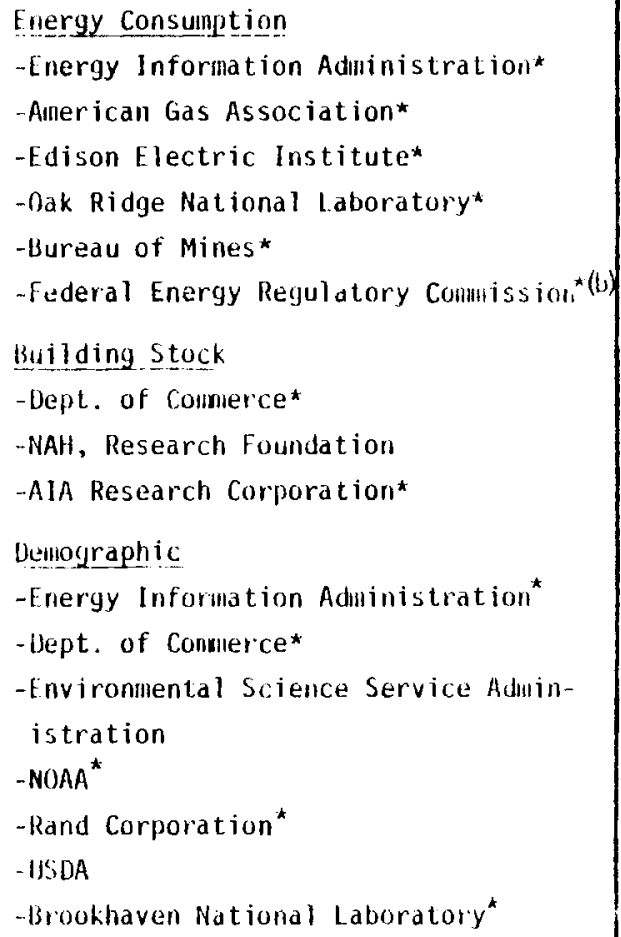 \\
\hline
\end{tabular}

* Dalda source used in Buildinas data book

(b) Some data from the Bureau of Mines and the federal Power Commission are now in EIA data bases 
GHEDU. INFOMATION NFEDS FOR NEA INPEFAENIAIION

LAW: NECPA

TITLE: II -- Residential Energy Conservation

PART: 2 -- Weatherization Grants for the Bentefit of Low Income Families

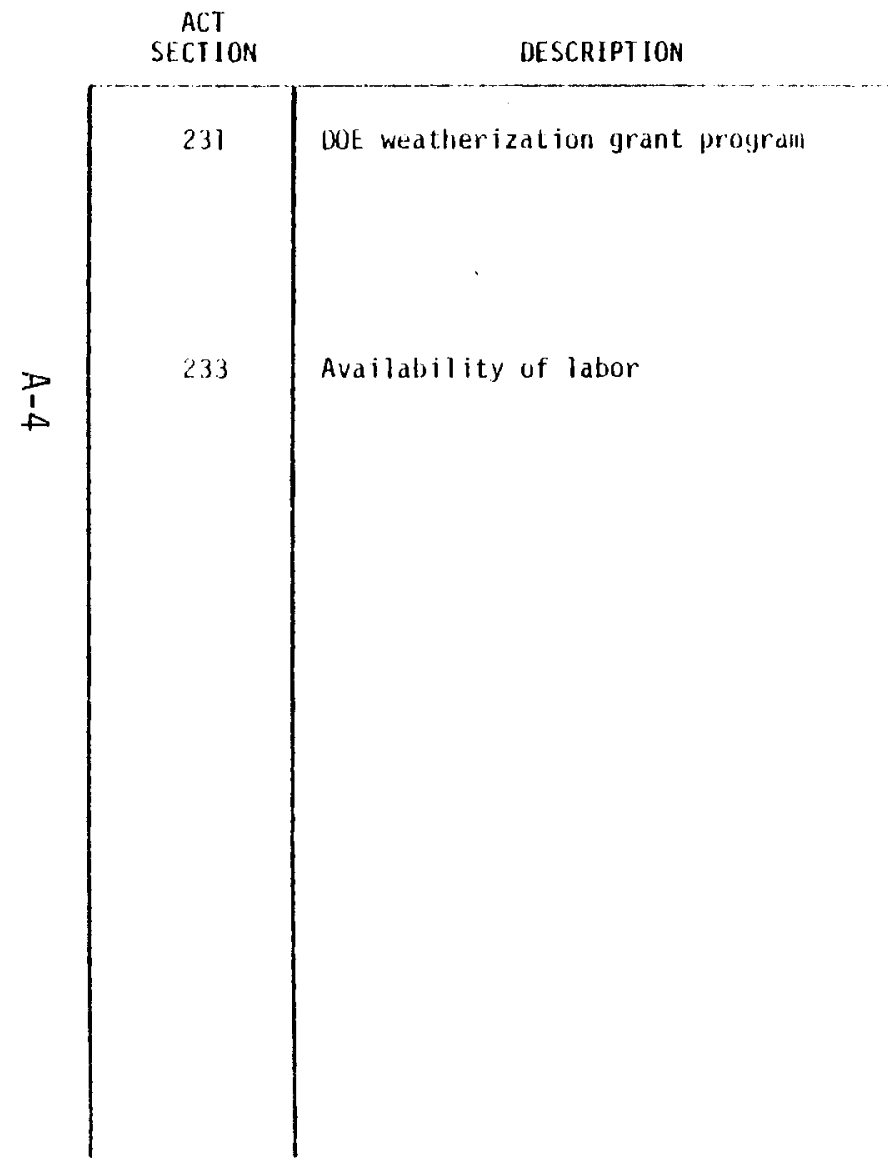

GENERAL INFORMATION NEEDS
Need baseline information on the cust-
effectiveness of conservation measures
(as per section $412(9)$ of F.C.E. B.A. of
1976 amended per this section)
Need information on the labor necessary
to carry out weatherization program in
various areas of country
Need information to identify areas of
councry with insufficient labor from
volunteers, training participants and
public service employecs

AFFECTL OFFICE

$\operatorname{BCS}$

\section{POTLITIAL LATA SOURCES}

\section{-State Agencies}

-Bureau of Census, Dept. of Commerce

- Aillerican Gas Association*

-Edison Electric Institute*

-Department of Labor

-Community Services Administration

-State Enployment offices

State Helfare offices

- Gata source used in buildings data boos 


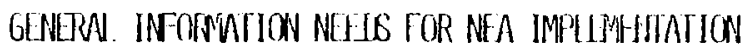

LAW: NECPA

TITLE: II - - Residential Energy Conservation

PART: 4 -- Miscellaneous

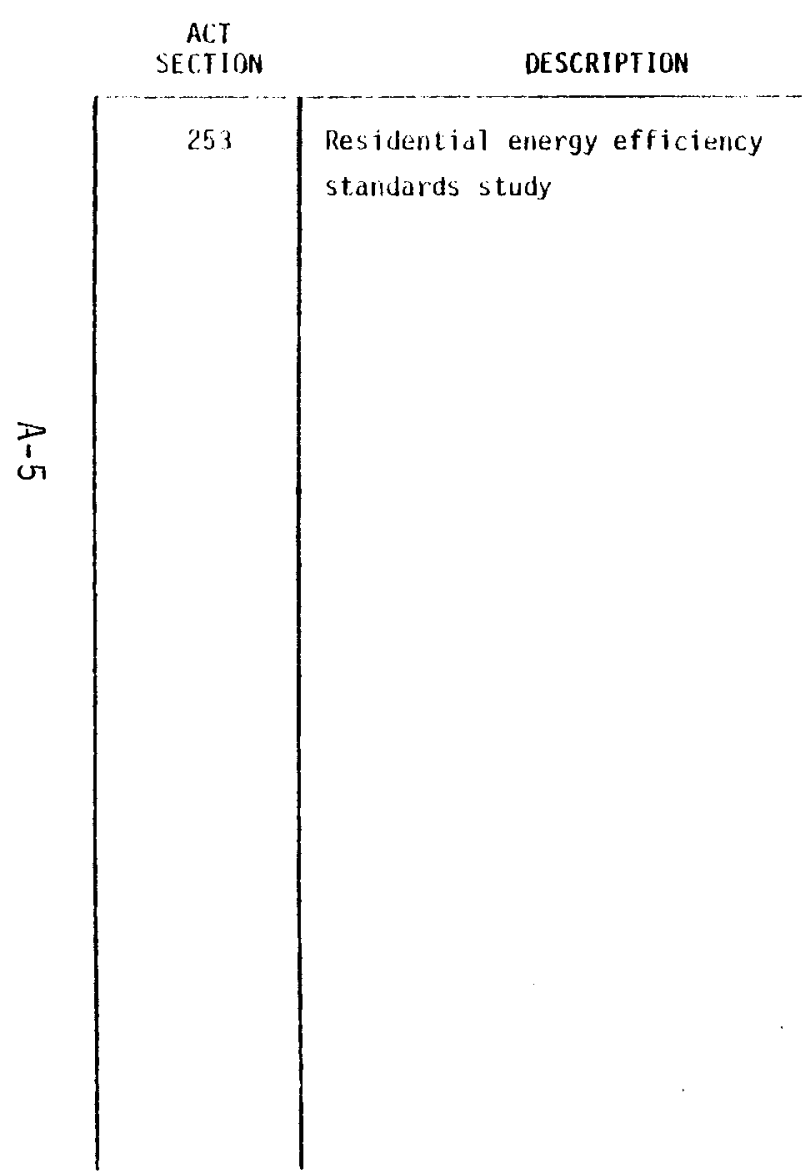

GENERAL INFORMAIION NEEDS
Information on:
- Energy savings due to conservation
efforts
- Impact on national economy and security
Also information on:
- Decision naking behavior of homle pur-
chasers
- Impact on real estate, home building
and inortgage/banking institutions
- Incentives and barriers on imillemen-
tation
- Inpact on sellers and purchasers
-[ftects on availability of credit
-Effects on available homes
- Inindet on volunteer conservation
efforts

AFIECTEU

OFFICE

POTENTIAL DATA SOURCES

BCS

(Same as section 212 and 224) 
GENERAL INFORMATION NEEDS FOR NEA IMPIEMLNTAIION

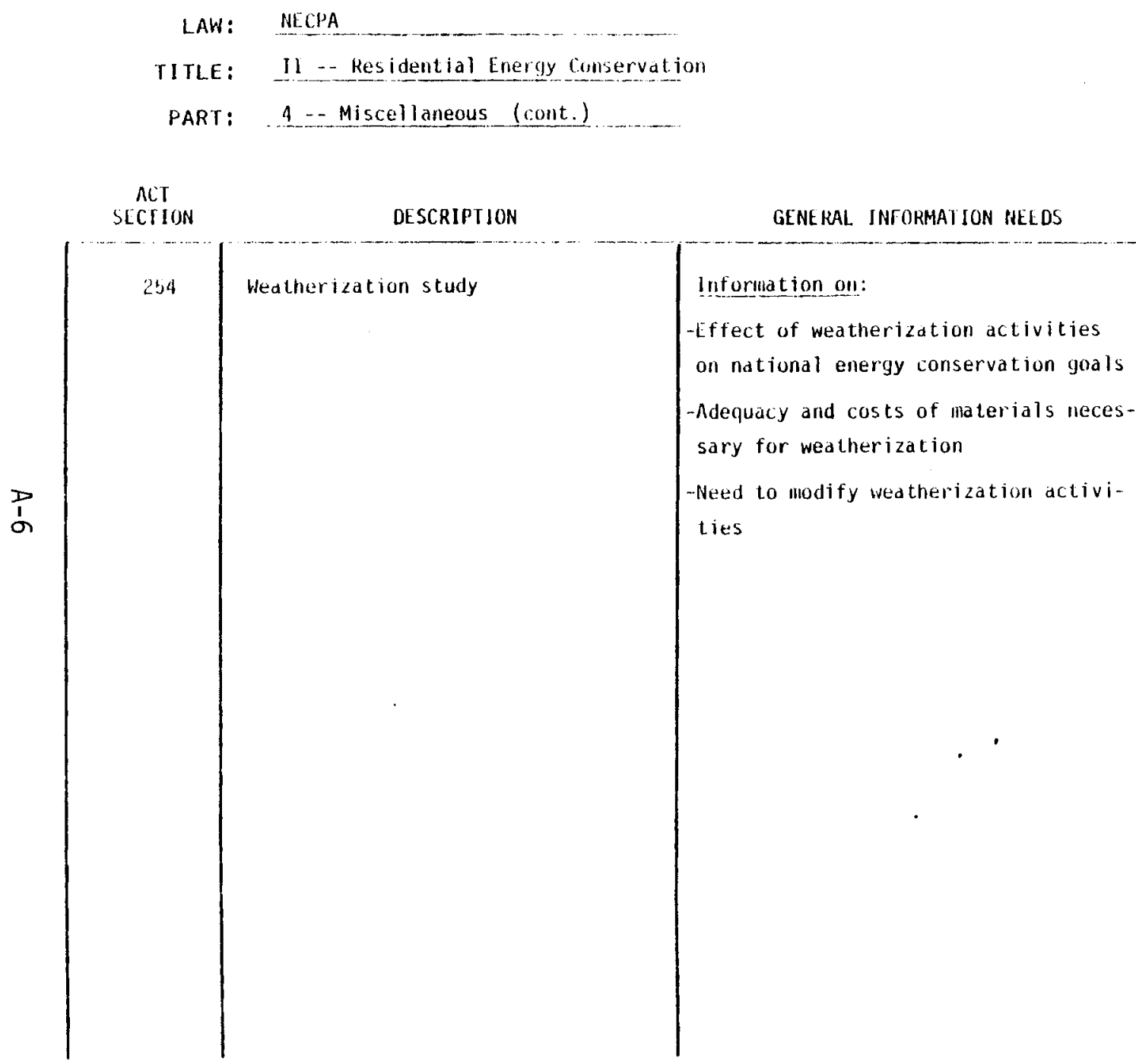

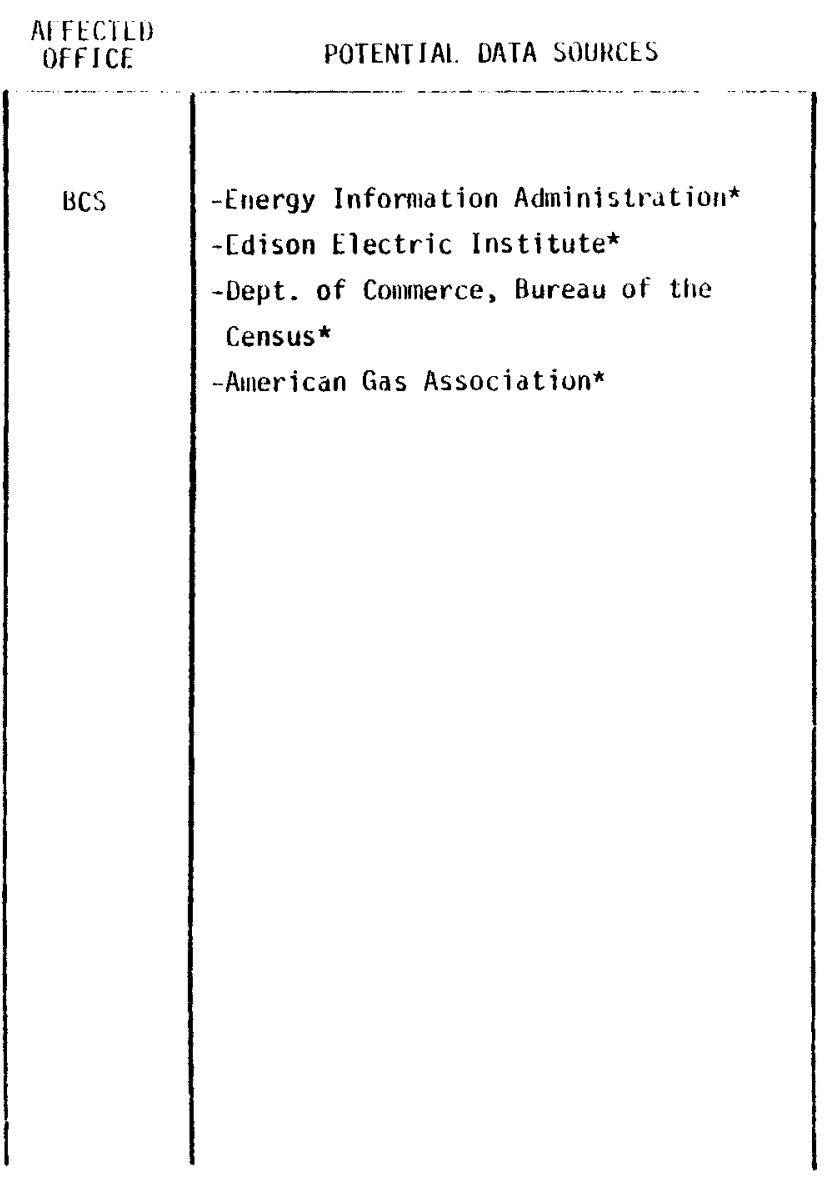

* Dala source used in Buildings data book 
LAW: NECPA

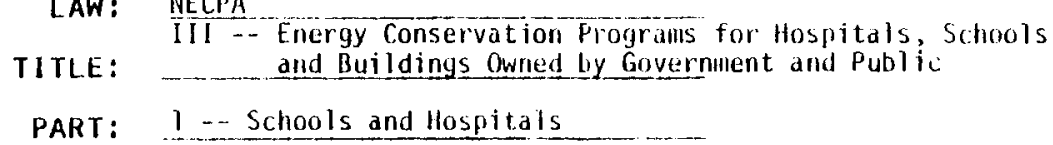

\begin{tabular}{|c|c|c|c|c|}
\hline $\begin{array}{c}\text { ACT } \\
\text { SECTION }\end{array}$ & DESCRIPTION & GENERAL INFORMATION NEEDS & $\begin{array}{l}\text { MFtECTEU } \\
\text { OFFICE }\end{array}$ & POTENTIAL DATA SOURCES \\
\hline 302 & $\begin{array}{l}\text { Guidel ines for energy conservation } \\
\text { progran for schools and hospitals } \\
\text { (Amendment to EPCA Title III Section } \\
392 \text { ) }\end{array}$ & $\begin{array}{l}\text { - Information to characterize buildings } \\
\text { by type, age, climatic region, etc. } \\
\text { - Baseline information on onergy con- } \\
\text { sumption } \\
\text { - Baseline information on environmental } \\
\text { and health requiremerits } \\
\text { - Information on economic characteris- } \\
\text { tics of areas where buildings are } \\
\text { localed } \\
\text { Intormation on the costs lo operate } \\
\text { buildings } \\
\text { - Information on costs to retrofit to } \\
\text { mect conservation goals } \\
\text { - Findncial information to determine } \\
\text { dmount of subsidy needed }\end{array}$ & $B C S$ & 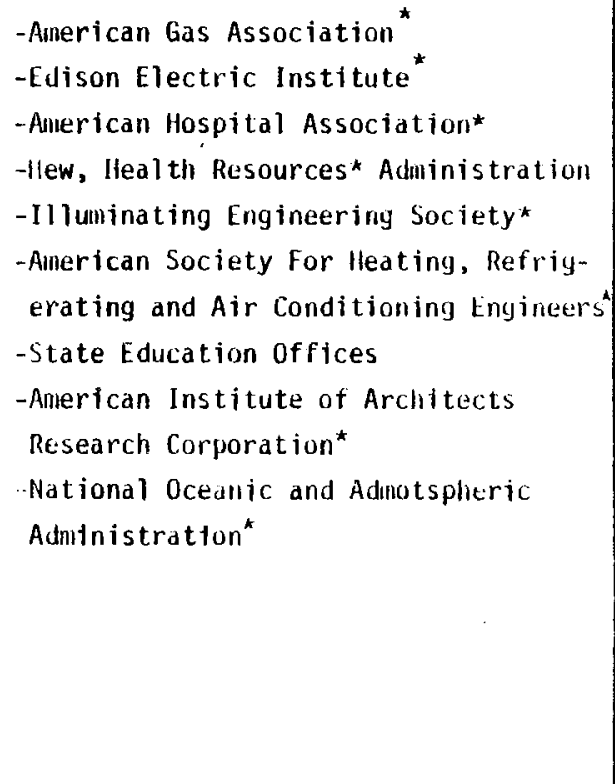 \\
\hline
\end{tabular}

* Dala source used in Buildings dala book 
LW:

In - Energy Conservation Programs for llospitals, Schools

TITLE: and Buildings Owned by Government and Publir

PART: 2 -- Units of Local Government and Public Care Institutions

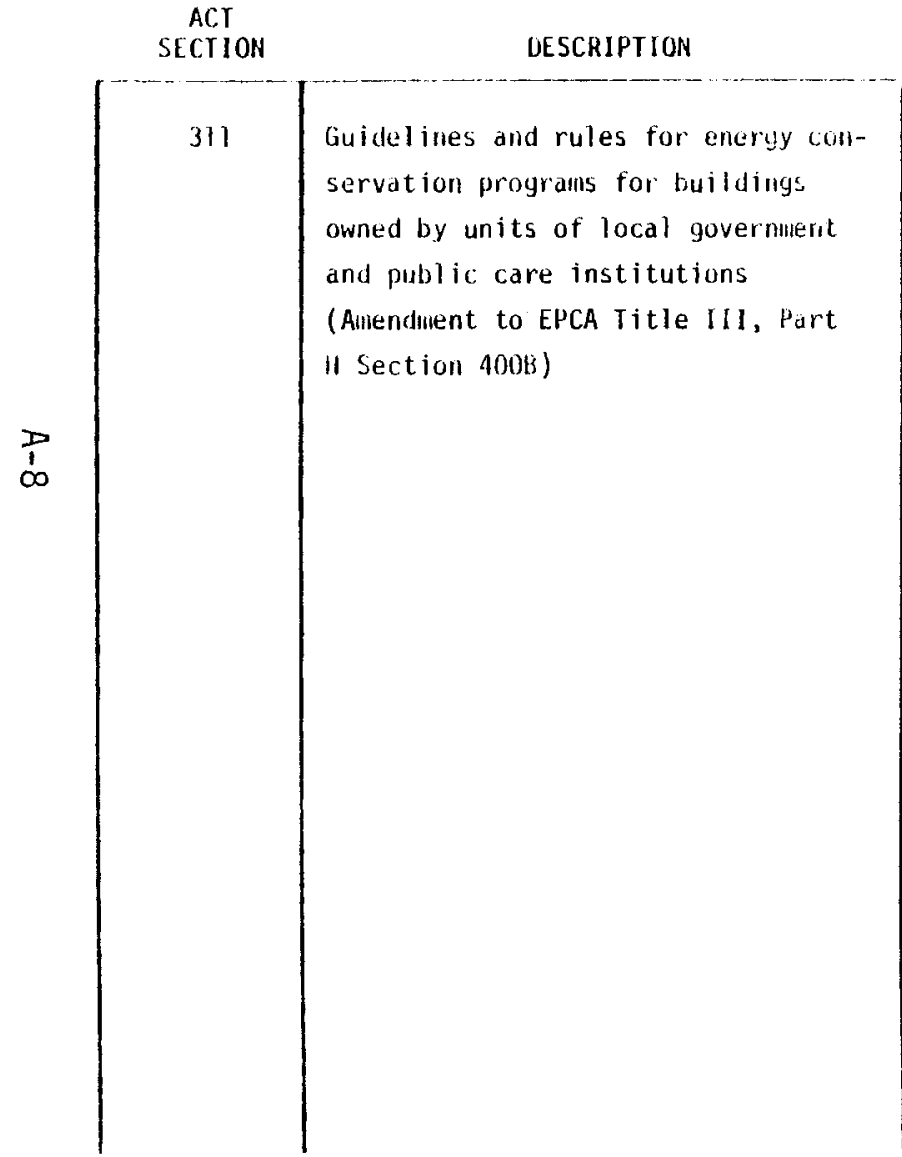

GENERAL INFORMATION NEEDS
Need information:
-To characterize buildings by type,
age, climatic region, etc.
-ro deternine a baseline on energy con-
sumption
-ro determine baseline on environmental
and health requirements
-0n economic characteristics of regions
where buildings are locaterl
-0n costs of operating buildinys
-0n costs of retrofit to mect conserva-
tion godls
-Findncial status of local governments
and capacity tu cover part of the
costs

AFFECTED

OFFICE

BCS

BCS

-American Institute of Architects ${ }^{\star}$ Research Corporation

-American Gas Associatior.

-Edison Electric Institute

-HEW, Health Resources Administration

-Energy Information Administration*

-Oak Ridge National Laboratory

- linta source used in Buildinys dala burk 
LAW: MECPA

TITLE: IV - Eneryy Efficiency of certain Products and Proresses

PART: 2 -- Energy Efficiency Standards for Consumer Products

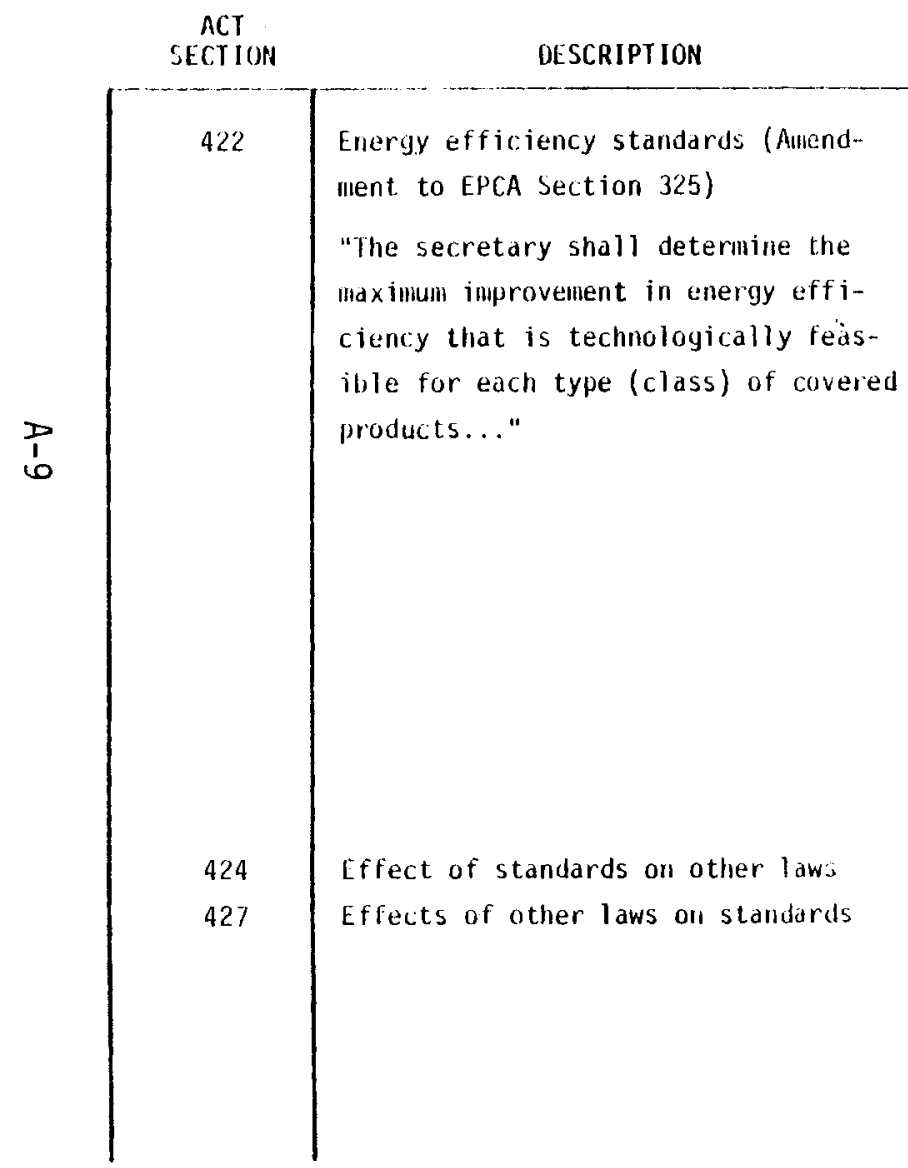

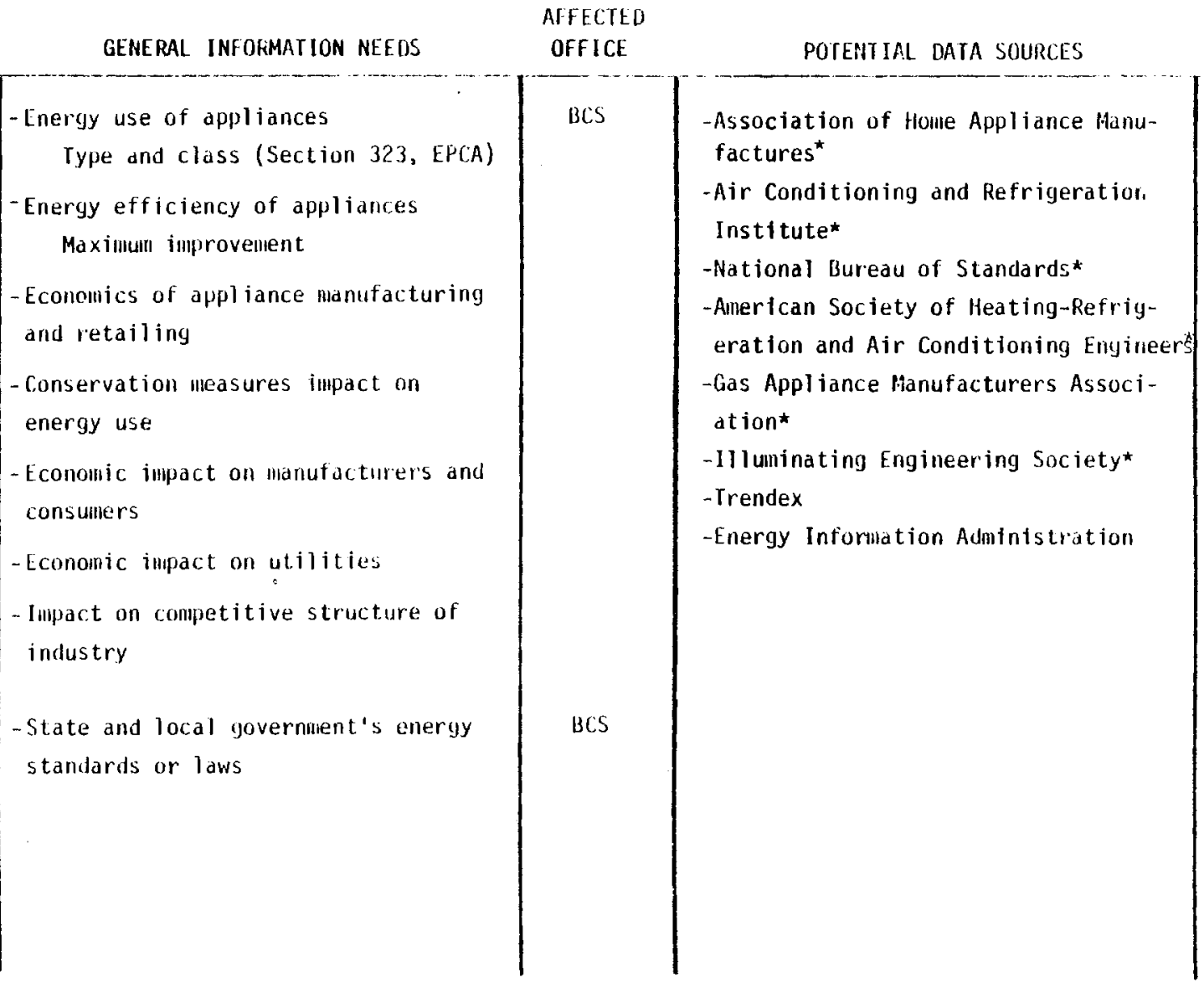

- Chata source used in Builuings data book 
LAW: HLCPA

TITLE: IV - Energy Efficiency of Certail Produrts and Processes

PART: 3 -- Energy Efficiency of Industrial Equipment

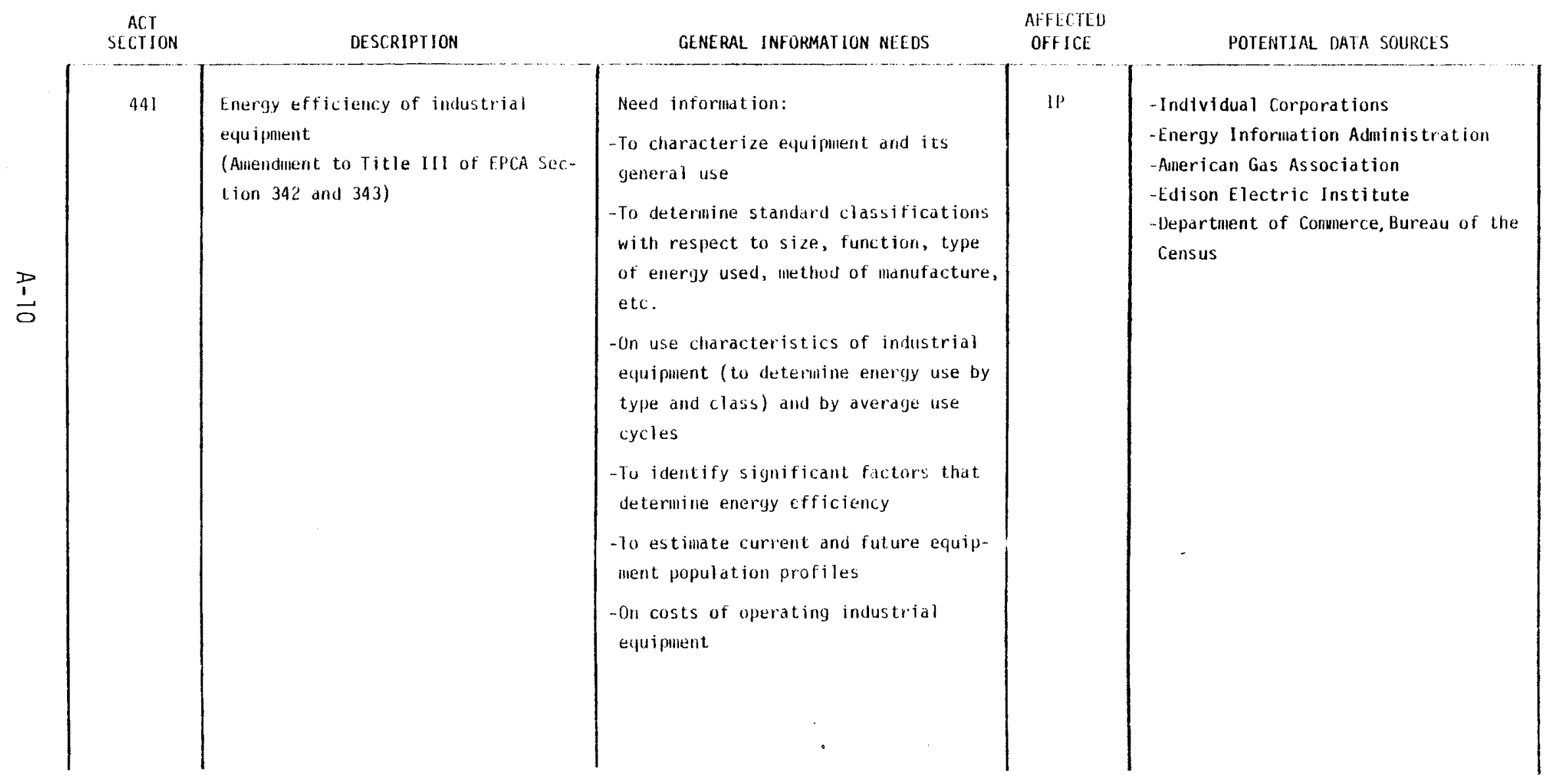


GENERAL INFURMATION NGEDS FOR MEA IMPLLMENTAIIOH

LAW: NECPA

TITLE: IV -- Energy Effjcjency of Cerkdin Products and Processes

PART: 4 -- Energy Efficiency by Use of Recovered Materials

\begin{tabular}{|c|c|c|c|c|}
\hline $\begin{array}{l}\text { ACI } \\
\text { SECTION }\end{array}$ & DESCRIPIION & GENERAL INFORMATION NEEDS & $\begin{array}{l}\text { FFECILD } \\
\text { OFFICE }\end{array}$ & PUTENTIAL DATA SOURCES \\
\hline 461 & $\begin{array}{l}\text { Use of recovered materials } \\
\text { (Amendment to EPCA Title III, Part E, } \\
\text { Section 374A) }\end{array}$ & $\begin{array}{l}\text { Need infornation: } \\
\text {-On energy use profiles of affected } \\
\text { industries } \\
\text { - To identify potencial recoverable mat- } \\
\text { erials (type and quantity and use) } \\
\text {-On economic impact on manufacturer } \\
\text { from the implementation of the } \\
\text { rules } \\
\text {-On state-of-the-art of recovery } \\
\text { processes }\end{array}$ & IP & $\begin{array}{l}\text {-Individual Corporations } \\
\text {-Energy Information Administration } \\
\text { (Survey Being Planned) } \\
\text {-Department of Commerce Bureau of } \\
\text { the Consus } \\
\text {-American Gas Association } \\
\text {-Edison Electric Institute }\end{array}$ \\
\hline
\end{tabular}


GENFRAL INFORMAIION NEEDS FOR NEA IMPIEMENIAIION

LAW: NECPA

IITLE: $\quad Y-$ Federal Energy Initiative

PART: 2 -- Demonstration of solar lleating and Cooling in Federal Buildings

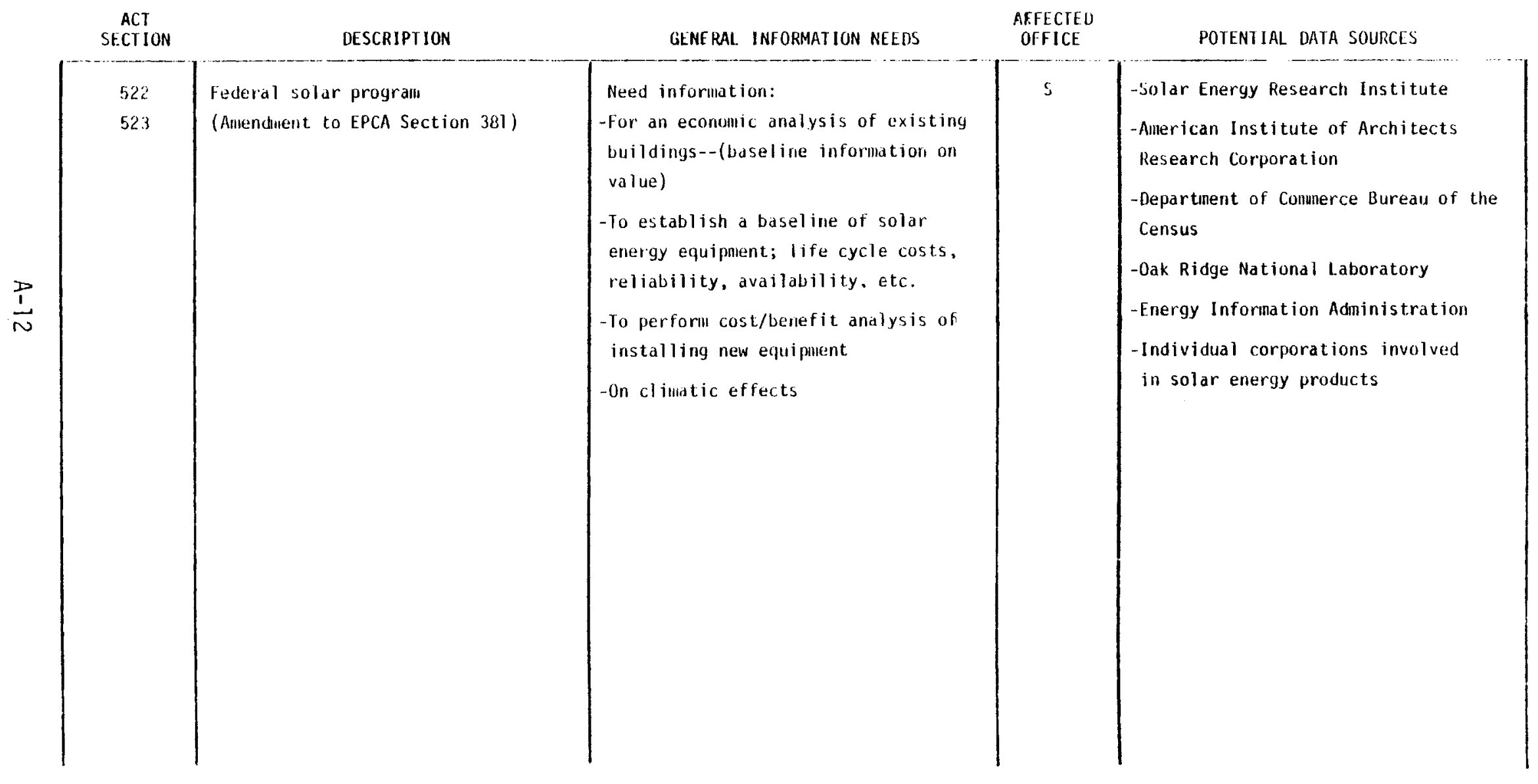


LAW: NECPA

TITLE: $\quad \underline{-}-$ Federal Energy Initiative

PART: 3 -- Eneray Conservation and solur Energy in Federal Buildiugs

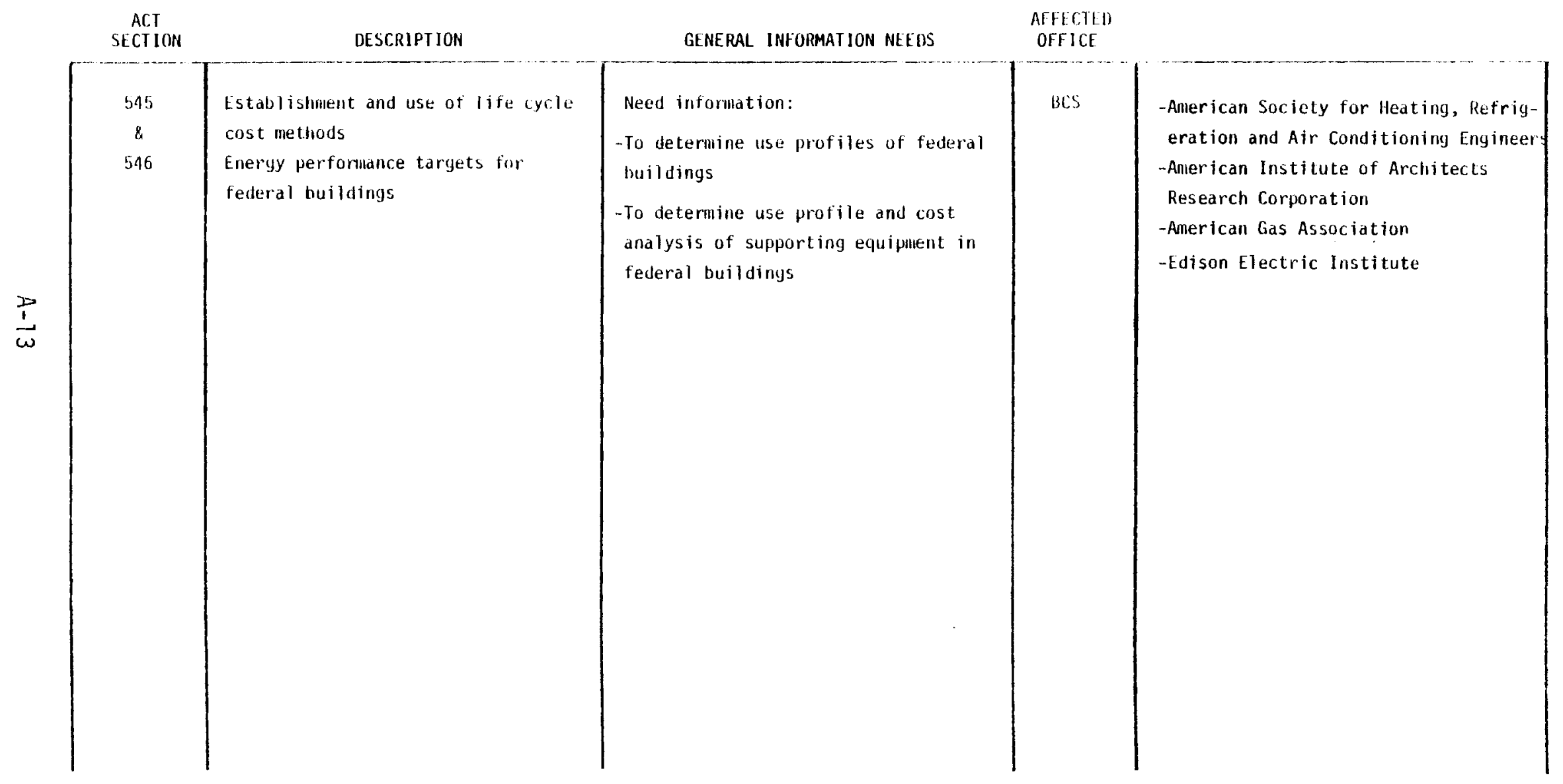


GENERAL INFORMATION NLEDS FOR NLA IMPLIMENIAIION

LAW: NECPA

TITLE: $\quad V$ - Federal Energy Initiative

PART: 4 -... Federal Photovoltaic utilization

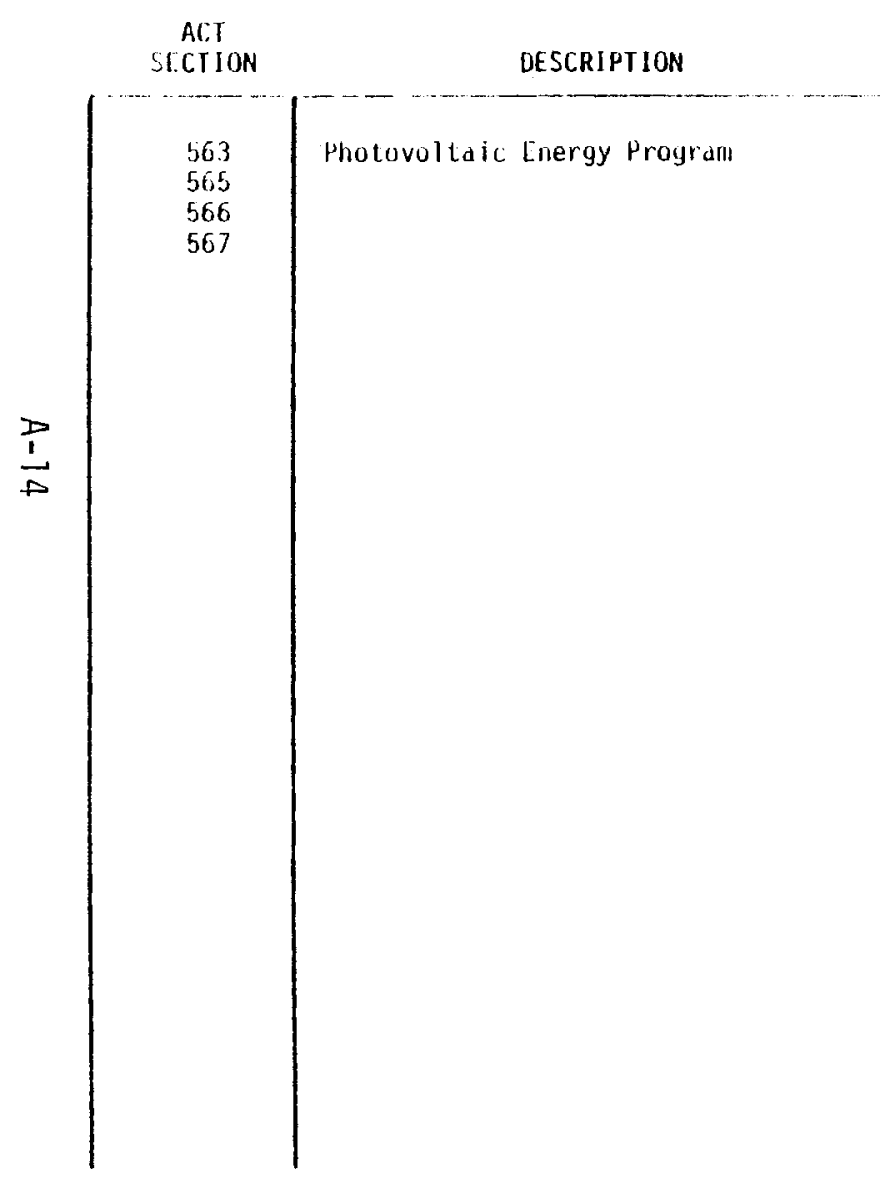

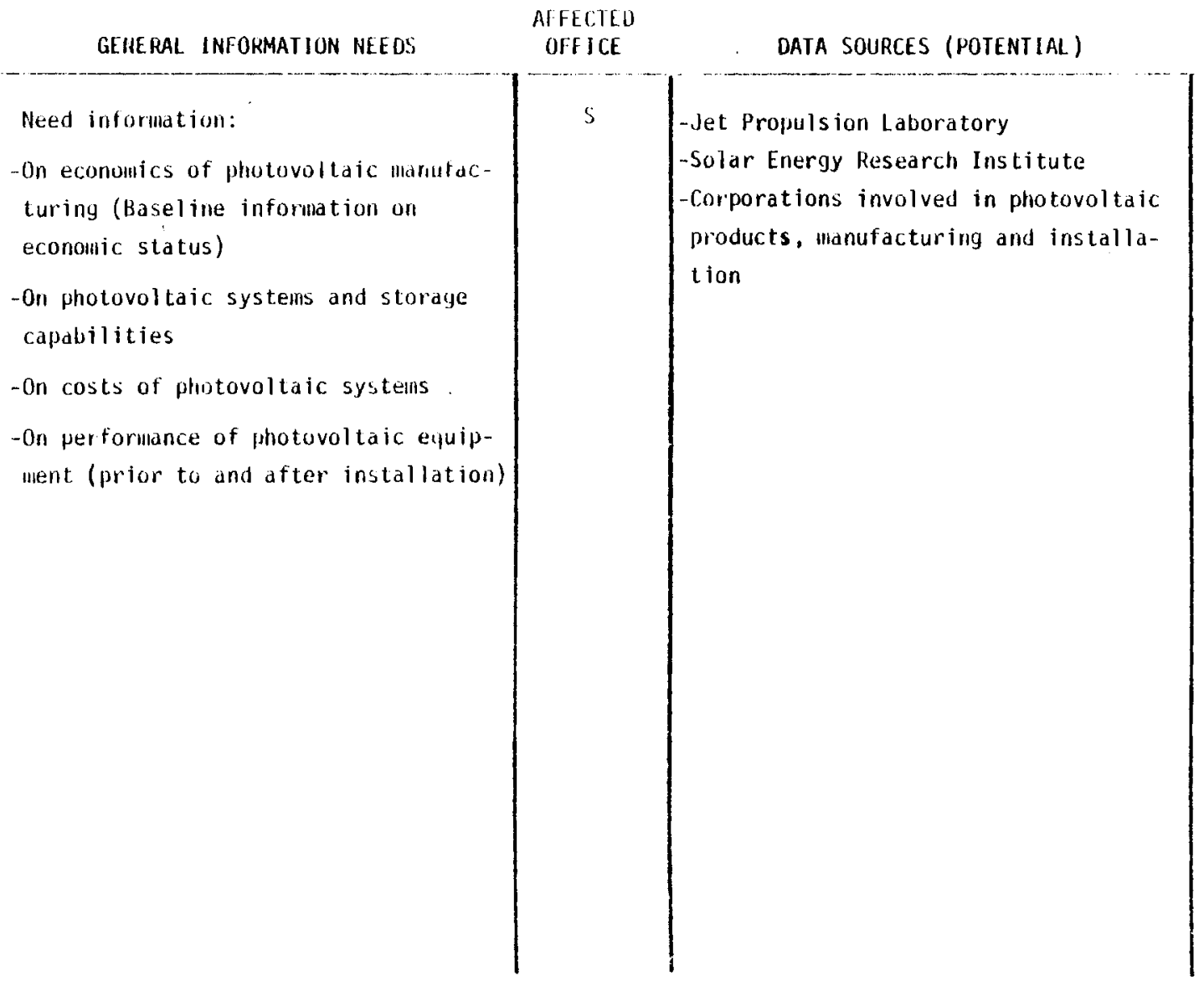


GENERAL INFORMATION NLEDS FOR NEA IMPLEMLETATION

LAW: HECEA

TITLE: VI -- Additional Energy-Rleated Measures

PART: $\quad 1$ - Industrial Energy Efficiency Reporting

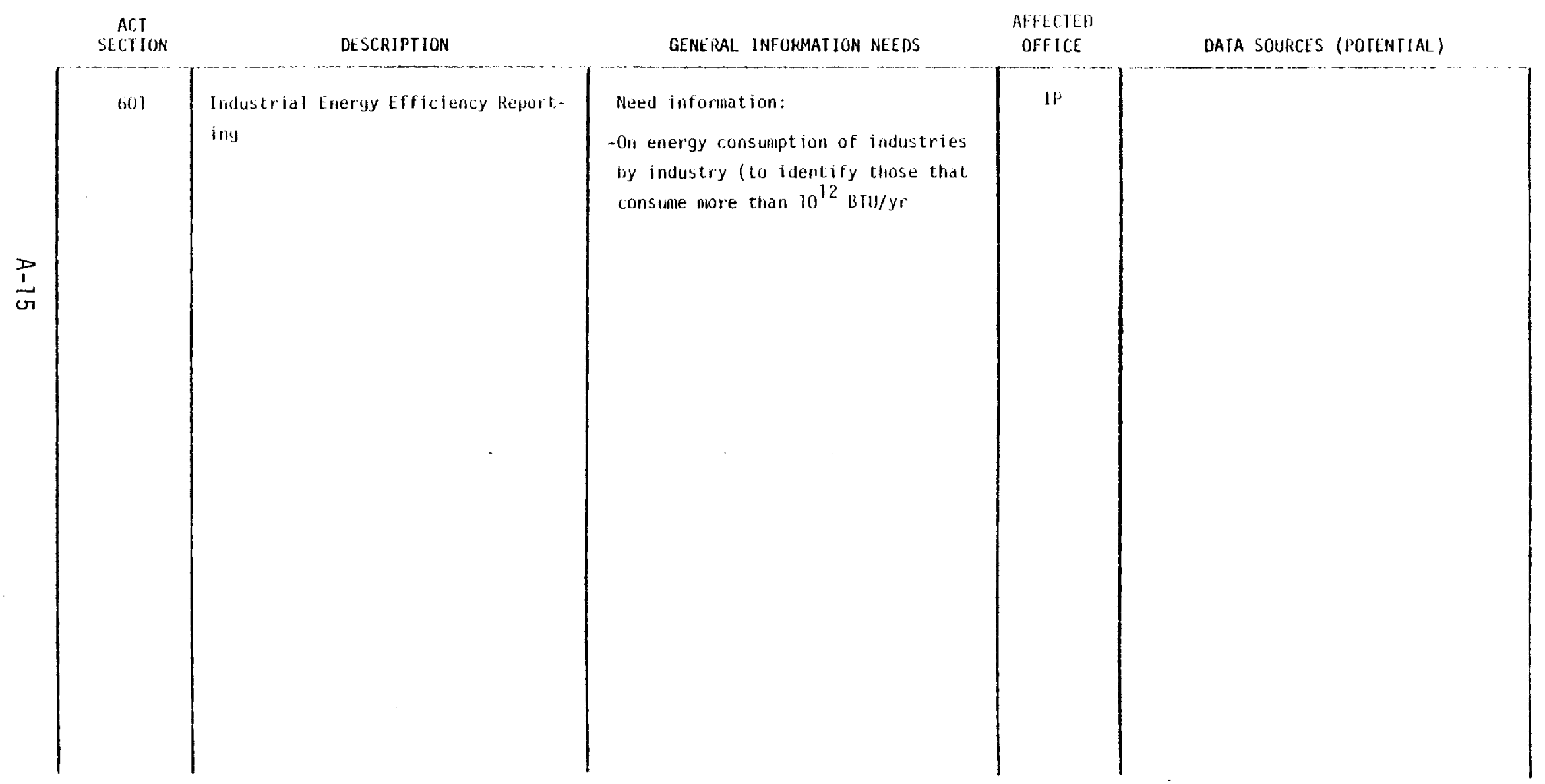


GENERAL. INFORMATION FOR NEA IMF'LEMENTATION

LAW: NEA, Energy Tax Act

TITLE: II - Transportation

PART: 2 -- Motur Fuels

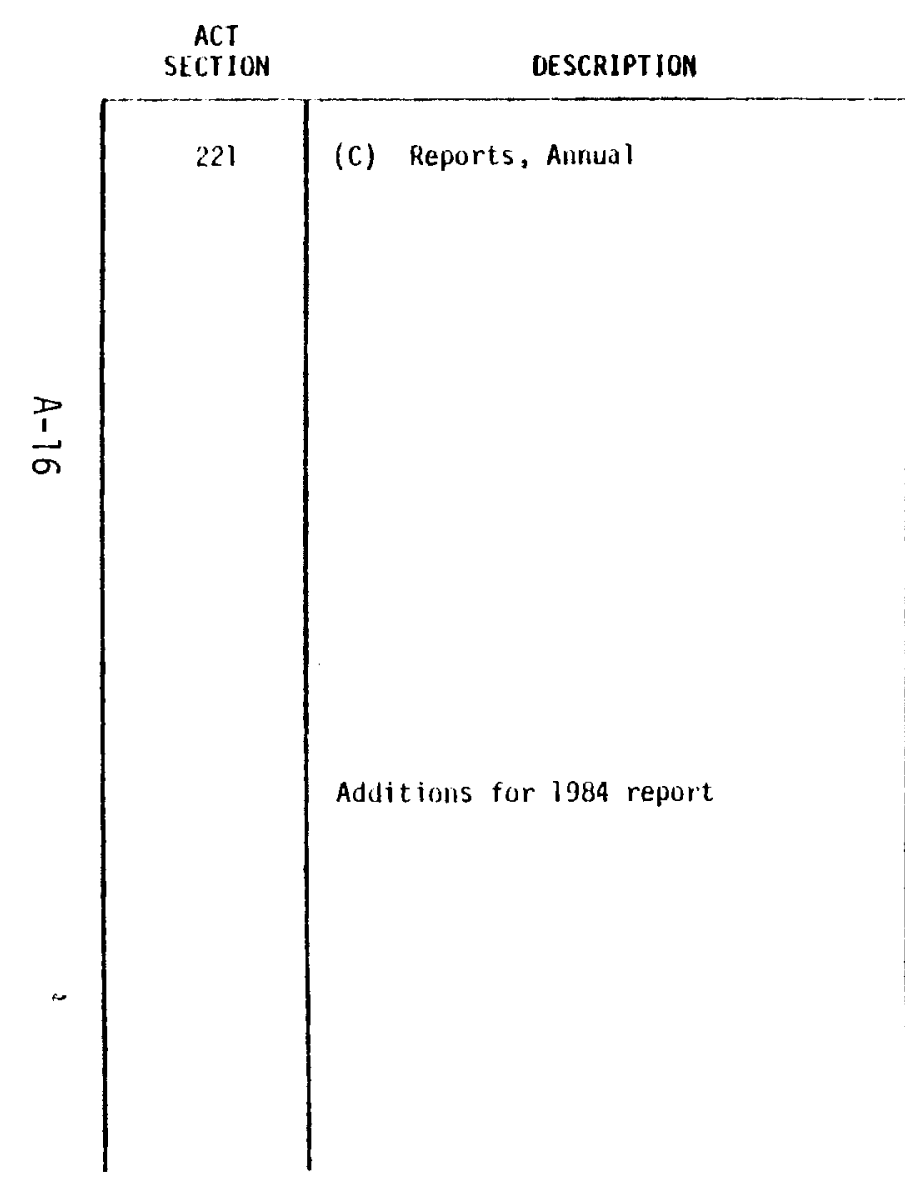

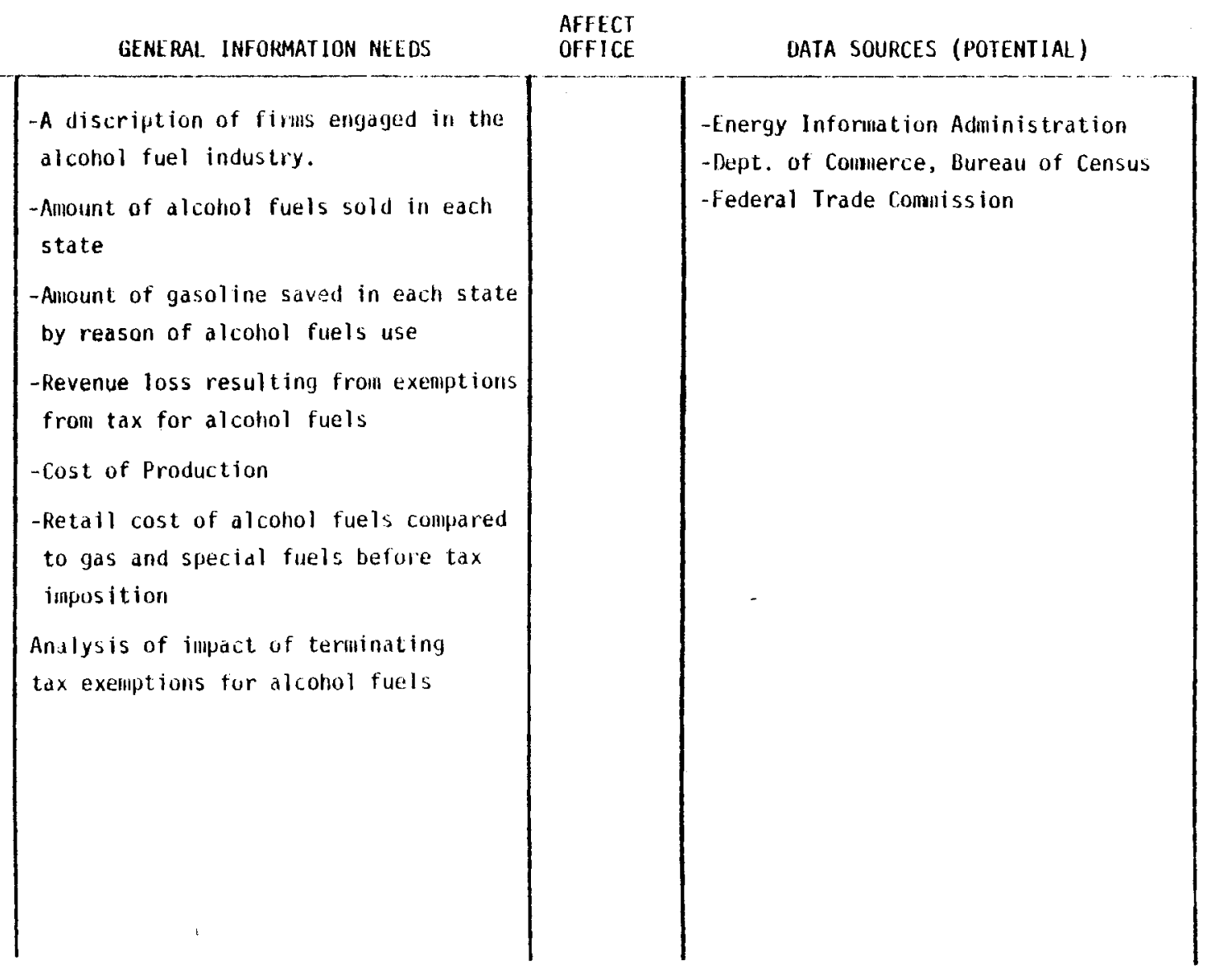


GENERAL. INFORMATION FOR NF IMPLEMENTATION

LAW: NEA Energy TaxAct _ _. _ _ _

TITLE: III-- Investment fax credit.

PART: 1

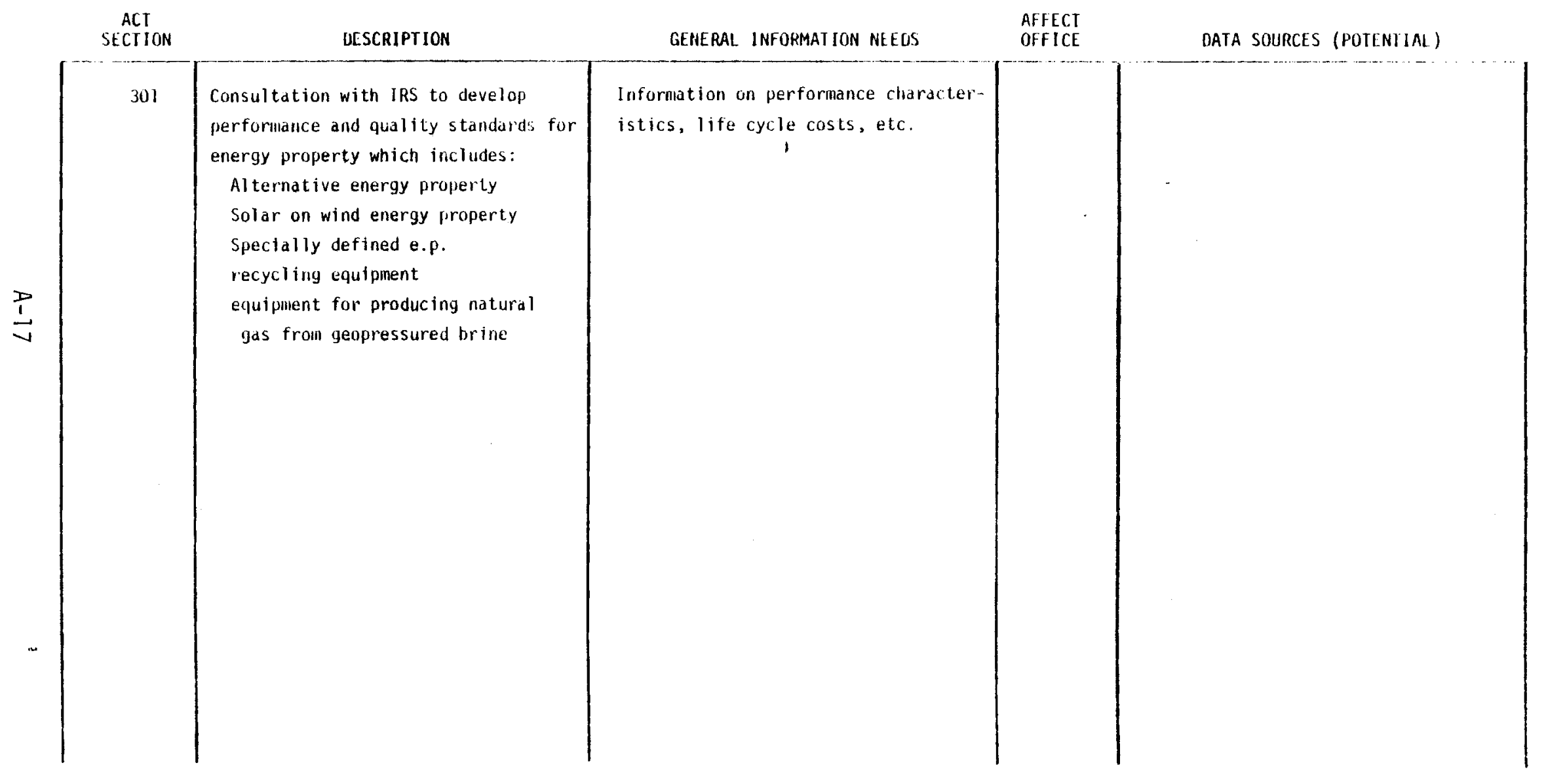




\section{APPENDIX B}

POTENTIAL SOURCES OF ENERGY RELATED DATA 


\section{POTENTIAL SOURCES OF ENERGY-RELATED DATA}

\section{FEDERAL}

1. Alaska Power Administration

2. Appalachian Regional Commission

3. Bonneville Power Administration

4. Council on Environmental Quality

5. Department of Commerce

- National Bureau of Standards

- Bureau of the Census

6. Community Services Administration

7. Department of Defense

- Department of the Army, Corps of Engineers

8. Delaware River Basin Commission

9. Department of Energy

- Energy Information Administration

- Office of Conservation and Solar Applications

- Federal Energy Regulatory Commission

10. Environmental Protection Agency

11. Department of Health, Education, and Welfare

- Public Health Service, Health Resources Administration

- National Institute of Health

12. Department of Housing and Urban Development

13. Department of Interior

- Bureau of Mines

14. Interstate Commerce Commission

15. Department of Labor

- Occupational Safety and Health Administration

16. National Science Foundation

17. Southeastern Power Administration

18. Southwestern Power Administration

19. Tennessee Valley Authority

20. U.S. Geological Survey 


\section{STATE}

1. Alabama - Energy Management Board Development Office; Office of the Governor

2. Alaska - Division of Energy and Power Development; Department of Commerce and Economic Development

3. Arizona - Energy Programs Section; Office of Economic Planning and Development; Office of the Governor

4. Arkansas - Energy Conservation and Policy Office

5. California - California Energy Commission

6. Colorado - Office of the Governor

7. Connecticut - Energy Division; Office of Policy and Management

8. Delaware - Energy Office; Executive Office of the Governor

9. Florida - State Energy Office; Department of Administration

10. Georgia - Energy Resources Division; Office of Planning and Budget

11. Guam - Guam Energy Office

12. Hawaii - State Energy Office; Department of Planning and Economic Development

13. Idaho - Office of Energy; Office of the Governor

14. Illinois - Institute of Energy and Environmental Resources

15. Indiana - Indiana Energy Office; Department' of Commerce

16. Iowa - Energy Policy Counci1

17. Kansas - Kansas Energy Office

18. Kentucky - Department of Energy; Capital Plaza Tower

19. Louisiana - Division of Research and Development; Department of Natural Resources

20. Maine - Office of Energy Resources; Executive Department

21. Maryland - Office of Energy Policy; Energy and Coastal Zone Administration; Department of Natural Resources

22. Massachusetts - Massachusetts Energy Office

23. Michigan - Energy Administration; Department of Commerce

24. Minnesota - Minnesota Energy Agency

25. Mississippi - Fuel and Energy Management Commission; Office of the Governor

26. Missouri - Missouri Energy Program; Division of Policy Development; Department of Natural Resources 
27. Montana - Energy Division; Department of Natural Resources and Conservation

28. Nebraska - State Energy Office; Department of Revenue

29. Nevada - Department of Energy

30. New Hampshire - Council on Energy; Executive Department; Office of the Governor

31. New Jersey - Department of Energy

32. New Mexico - Energy and Minerals Department

33. New York - New York State Energy Office

34. North Carolina - Energy Division; Department of Commerce

35. North Dakota - Energy Management and Conservation Office; Office of the Governor

36. Ohio - Department of Energy

37. Ok lahoma - Department of Energy

38. Oregon - Department of Energy

39. Pennsylvania - Governor's Energy Council; Office of the Governor

40. Puerto Rico - Energy Office; Office of the Governor

41. Rhode Is land - Governor's Energy Office

42. South Carolina - South Carolina Energy Management Office

43. South Dakota - Office of Energy Policy

44. Tennessee - Tennessee Energy Authority

45. Texas - Governor's Office of Energy Resources

46. Utah - Energy Conservation and Development Counci1; Department of State Planning

47. Vermont - State Energy Office; Agency of Administration

48. Virgin Islands - Virgin Islands Energy Office

49. Virginia - Energy Division; Office of Emergency and Energy Services

50. Washington - State Energy Office

51. West Virginia - Fuel and Energy Office; Governor's Office of Economic and Community Development

52. Wisconsin - Office of State Planning and Energy; Department of Administration

53. Wyoming - Energy Conservation Committee 
PRIVATE

American Chemical Society

American Gas Association

American Hospital Association

American Institute of Chemical Engineers

American Institute of Mining, Metallurgical, and Petroleum Engineers

American National Standards Institute

American Nuclear Society

American Petroleum Institute

American Power Conference

American Public Health Association

American Society for Heating, Refrigerating and Air Conditioning Engineers

American Society of Mechanical Engineers

Argonne National Laboratories

Battelle Northwest Laboratories

Colorado School of Mines Research Institute

Edison Electric Institute

Electric Power Research Institute

Environmental Research Institute

Institute of Electrical and Electronics Engineers

Institute of Gas Technology

Kansas State University, Engineering Experiment Station

Lawrence Berkley Laboratory

National Academy of Science

National Coal Association

National 0 i] Fuel Institute

National Petroleum Council

National Resources Analysis Center

Natura] Gas Processors Association

National Resources Research Institute, University of Wyoming

Oak Ridge National Laboratory

Power Information Center, Unviersity of Pennsylvania 
Rand Corporation

Resources for the Future, Inc.

Solar Energy Research Institute

Solar Energy Society

B. 5 
APPENDIX C

ENERGY-RELATED PUBLIC LAWS ENACTED

FROM THE 91st TO THE 95th CONGRESS 
ENERGY-RELATED PUBLIC LAWS ENACTED

FROM THE 91st TO THE 95th CONGRESS

\begin{tabular}{|c|c|}
\hline $\begin{array}{r}\text { Public } \\
\text { Law \# }\end{array}$ & $\begin{array}{c}\text { Legislativ } \\
\text { Basis } \\
\end{array}$ \\
\hline 1. PL $91-158$ & S.J.Res. 5 \\
\hline 2. PL $97-173$ & 5.2917 \\
\hline 3. PL $97-245$ & S. 1193 \\
\hline 4. PL 9$\}-581$ & 5.368 \\
\hline 5. PL $91-631$ & 5.719 \\
\hline 6. PL 92-84 & H.R. 9388 \\
\hline 7. PL 92-307 & H.R. 74655 \\
\hline 8. $P L$ 92-314 & 5.3607 \\
\hline 9. PL $92-401$ & H.R. 50565 \\
\hline 10. PL $92-500$ & 5.2770 \\
\hline \multirow[t]{2}{*}{ 11. PL 92-583 } & 5.3507 \\
\hline & S.Res. 45 \\
\hline 12. PL 93-28 & 5.398 \\
\hline 13. PL 93-69 & 5.1994 \\
\hline 14. PL 93-74 & H.R. 7528 \\
\hline 15. PL 93-87 & 5.502 \\
\hline 16. PL $93-88$ & 5.1993 \\
\hline 17. PL 93-119 & H. R. 5451 \\
\hline 18. PL $93-153$ & S. 1081 \\
\hline 19. PL 93-159 & S. 1570 \\
\hline 20. PL $93-182$ & H.R. 11324 \\
\hline 21. PL $93-208$ & 5.2794 \\
\hline 22. PL 93-239 & H.R. 11372 \\
\hline 23. PL $93-245$ & H.R. 11576 \\
\hline 24. PL $93-248$ & A. 1070 \\
\hline 25. PL $93-249$ & S.J.Res. 18 \\
\hline 26. PL $93-276$ & 5.3292 \\
\hline 27. PL $93-316$ & H.R. 13998 \\
\hline 28. PL $93-319$ & H.R. 14368 \\
\hline 29. PL 93-322 & H.R. 14434 \\
\hline 30. PL $93-377$ & 5.3669 \\
\hline 31. PL 93-383 & 5.3066 \\
\hline 32. PL $93-386$ & 5.3331 \\
\hline 33. PL $93-403$ & H.R. 15205 \\
\hline 34. PL $93-409$ & H.R. 11864 \\
\hline
\end{tabular}

- name

CS

Related

Interstate 0 il Compact Cormission, 2-Year Extension

Coal Mine Heal th and Safety Act of 1969

011 and Gas Leases

Geothermal Steam Act of 1970

National Mines and Minerals Policy Act

Atomic Energy Cormission Authorization, 1972

Temporary Operating Licenses for Nuclear Powerplants

Atomic Energy Commission Appropriations, 1973

Natural Gas Pipeline Safety Act of 1968

Federal Water Pollution Control Act Amend-

ments

Coastal Zone Management Act of 1972

To establish the Senate National Fuels and Energy Policy Study Group

Economic Stabilization Act Amendments of 1973; Voluntary Petroleum Allocation

AEC Authorization

NASA Authorization

Federal-Aid Highway

Euratom Corporation Act of 1958 Amendments

0 il Pollution Act Amendments

Mineral leasing Act of 1920, Amendments, and and Trans-Alaska 0 il Pipeline Authorization

Emergency Petroleum Allocation Act of 1973

Emergency Daylight Saving Time Energy Conservation Act of 1973

G. [. Bill Benefits During Energy Crisis Highway Speed Limit Reduction

Supplemental Appropriations; Naval Petroleum Reserves

Intervention on the High Seas Act

Truckers fuel costs

AEC Authorization

NASA Authorization

Energy Supply and Environmental Coordination Act of 1974

Special Energy Research and Development

Appropriations for 1975

AEC Omnibus Legislation of 1974

Housing and Conmunity Development Act

Aid to Energy Affected Small Businesses

Natural Gas Pipeline Safety Act, as Amended, Additional Appropriations

Solar Heating and Cooling Demonstration Act of 1974 


\section{ENERGY-RELATED PUBLIC LAWS ENACTED}

\section{FROM THE 91st TO THE 95th CONGRESS}

\begin{tabular}{|c|c|c|c|}
\hline $\begin{array}{l}\text { Public } \\
\text { Law \# }\end{array}$ & $\begin{array}{c}\text { Legislative } \\
\text { Basis }\end{array}$ & Name & $\begin{array}{c}C S \\
\text { Related } \\
(x) \\
\end{array}$ \\
\hline 35. $P L 93-410$ & H.R. 14920 & $\begin{array}{l}\text { Geotherma } 1 \text { Energy Research, Development, } \\
\text { and Demonstration Act }\end{array}$ & $x$ \\
\hline 36. PL $93-426$ & 5.3270 & $\begin{array}{l}\text { Defense Production Act of } 1950,2 \text {-year } \\
\text { Extension }\end{array}$ & \\
\hline 37. PL $93-434$ & HR. 16102 & $\begin{array}{l}\text { Emergency Daylight Saving Time Energy Con- } \\
\text { servation Act of } 1973 \text {, Amendments }\end{array}$ & \\
\hline 38. PL $93-438$ & H.R. 11510 & Energy Reorganization Act of 1974 & $x$ \\
\hline 39. PL 93-454 & 5.3362 & Federal Columbia River Transmission System & \\
\hline 40. PL 93-473 & 5.3234 & $\begin{array}{l}\text { Solar Energy Research, Development and } \\
\text { Demonstration Act of } 1974\end{array}$ & $x$ \\
\hline 41. $P L 93-482$ & H.R. 11251 & Duty Free Entry of Methanol for use as Fuel & \\
\hline 42. PL $93-485$ & A. 3698 & International Nuclear Cooperation Act & \\
\hline 43. PL 93-496 & H.R. 15427 & National Railroad Passenger Corporation & \\
\hline 44. PL $93-511$ & H.R. 16757 & $\begin{array}{l}\text { Emergency Petroleum Allocation Act of } 1973 \\
\text { Extension }\end{array}$ & \\
\hline 45. PL $93-514$ & 5.3802 & Nuclear Information Annual Report & \\
\hline 46. PL $93-522$ & H.J.Res. 444 & Sequoia National Park Hydroelectric Project & \\
\hline 47. PL $93-577$ & 5.1283 & $\begin{array}{l}\text { Federal Nonnuclear Energy Research and } \\
\text { Development Act of } 1975\end{array}$ & $x$ \\
\hline 48. PL 93-627 & H.R. 10701 & Deep Water Ports Act & \\
\hline 49. PL $93-643$ & 5.3934 & $\begin{array}{l}\text { Federal-Aid Highway Act Amendments of 1975- } \\
\text { Fuel Exports to U.S.S.R. }\end{array}$ & \\
\hline \multirow[t]{4}{*}{ 50. PL $93-646$} & H.R. 15977 & Export-Import Bank Act Amendments & \\
\hline & S.Res. 138 & National Consumer Effort to Save Gas & $x$ \\
\hline & S. Res. 249 & 0il Price Increase & \\
\hline & S.Res. 279 & Washington Energy Conference & \\
\hline 51. PL 94-12 & H.R.2166 & $\begin{array}{l}\text { Tax Reduction Act of 1975; Repeal of Deple- } \\
\text { tion Al lowance }\end{array}$ & \\
\hline 52. PL $94-18$ & 5.994 & Nuclear Regulatory Commission Authorization & \\
\hline 53. PL 94-79 & 5.1716 & Nuclear Regulatory Commission Authorization & \\
\hline 54. PL $94-139$ & H.R. 9472 & TVA Bonding Authority & \\
\hline 55. PL $94-163$ & 5.622 & Energy Policy and Conservation Act & $x$ \\
\hline 56. PL $94-180$ & H.R. 8122 & Public Works--ERDA Appropriations 1976 & \\
\hline 57. PL 94-187 & H.R. 3474 & ERDA Authorization 1976 & \\
\hline 58. PL $94-197$ & H.R.8631 & Nuciear Accident Indemnity & \\
\hline 59. PL 94-227 & S.J.Res.59 & Internationa 1 Petroleum Exposition & \\
\hline 60. PL $94-258$ & H.R. 49 & $\begin{array}{l}\text { Naval Petroleum Reserves Production Act of } \\
1976\end{array}$ & \\
\hline 61. PL 94-269 & 5.3108 & ERDA Supplemental Authorization 1976 & \\
\hline 62. PL $94-291$ & $\$ .3107$ & Nuciear Regulatory Commission Authorization & \\
\hline 63. PL $94-332$ & 5.3625 & Federai Energy Administration Extension & \\
\hline 64. PL 94-355 & H.R. 14236 & Public Works--ERDA Appropriations, 1977 & \\
\hline 65. PL 94-364 & 5.1518 & $\begin{array}{l}\text { Motor Vehicle Information and Cost Savings } \\
\text { Act }\end{array}$ & $x$ \\
\hline 66. $\mathrm{PL} 94-730$ & 5.586 & $\begin{array}{l}\text { Coastal Zone Management Act Amendments, State } \\
\text { grants }\end{array}$ & \\
\hline 67. PL $94-377$ & 5.391 & Federal Coal Leasing Amendments Act & \\
\hline 68. PL $94-385$ & H.R. 12169 & Energy Conservation and Production & $x$ \\
\hline 69. PL 94-413 & H.R. 8800 & $\begin{array}{l}\text { Electric and Hybrid Vehicle Research, } \\
\text { Development and Demonstration Act of } 1976\end{array}$ & \\
\hline 70. PL $94-422$ & 5.327 & Land and Water Conservation Fund Act & \\
\hline
\end{tabular}


ENERGY-RELATED PUBLIC LAWS ENACTED FROM THE 91st TO THE 95th CONGRESS

\begin{tabular}{|c|c|c|c|}
\hline $\begin{array}{l}\text { Public } \\
\text { Law \# }\end{array}$ & $\begin{array}{c}\text { Legislative } \\
\text { Basis } \\
\end{array}$ & Name & $\begin{array}{l}\text { CS } \\
\text { Related } \\
(x) \\
\end{array}$ \\
\hline 71. PL $94-477$ & H.R. 12168 & Natural Gas Pipeline Safety & \\
\hline 72. PL $94-493$ & S.J.Res. 126 & [nterstate $0 \mathrm{il}$ and Gas Compact & \\
\hline 73. PL $94-586$ & S.3521 & Alaskan Gas Transportation & \\
\hline 74. PL $95-2$ & 5.474 & Emergency Natural Gas Act of 1977 & \\
\hline 75. PL $95-39$ & 5.36 & $\begin{array}{l}\text { ERDA Authorization Act of } 1977 \text { (Non- } \\
\text { nuclear) }\end{array}$ & \\
\hline 76. PL $95-70$ & S. 1468 & $\begin{array}{l}\text { Federal Energy Administration Authoriza- } \\
\text { tion Act of } 1977\end{array}$ & \\
\hline 77. PL 95-74 & H.R. 7636 & [nterior Appropriations for FY78 & \\
\hline 73. PL $95-87$ & H.R.2 & $\begin{array}{l}\text { Surface Mining Control and Reclamation Act } \\
\text { of } 1977\end{array}$ & \\
\hline 79. PL 95-91 & 5.826 & Department of Energy Organization Act & $x$ \\
\hline 80. PL $95-95$ & H.R. 6161 & Clean Air Act Amendments of 1977 & \\
\hline 81. PL $95-96$ & H.R. 7553 & Public Works Appropriations for Fy 78 & \\
\hline 82. PL $95-158$ & H.J.Res.621 & Alaska Natural Gas Transportation System & \\
\hline 83. PL $95-183$ & 5.1339 & $\begin{array}{l}\text { ERDA Authorization Act of } 1977 \text { and } 1978- \\
\text { Military Applications }\end{array}$ & \\
\hline 84. PL $95-236$ & 5.266 & $\begin{array}{l}\text { Authorization for Funds to Limit Radiation } \\
\text { Exposure from Uranium Mill Tailings used in } \\
\text { Construction }\end{array}$ & \\
\hline 85. PL $95-238$ & S. 1340 & $\begin{array}{l}\text { ERDA Authorization Act of } 1978 \text { - Civilian } \\
\text { Applications }\end{array}$ & \\
\hline 86. PL $95-240$ & H.R. 9375 & Supplemental Appropriations for FY78 & \\
\hline 87. PL $95-242$ & H.R. 8638 & Nuclear Non-Proliferation Act of 1978 & \\
\hline 88. PL 95-246 & H.J.Res. 746 & $\begin{array}{l}\text { Supplemental Appropriations for the } \\
\text { Southwestern Power Administration }\end{array}$ & \\
\hline 89. PL $95-253$ & H.J.Res. 715 & Sun Day Proclamation & $x$ \\
\hline 90. PL 95-297 & H.R. 130 & Petroleum Marketing Practices Act & \\
\hline 91. PL 95-315 & H.R. 11713 & Smali Business Energy Loan Act & $x$ \\
\hline 92. PL $95-319$ & $S .2401$ & $\begin{array}{l}\text { Emergency Interim Consumer Product } \\
\text { Safety Standards Act of } 1978\end{array}$ & $x$ \\
\hline 93. PL $95-372$ & 5.9 & $\begin{array}{l}\text { Outer Continental Shelf Lands Act of } \\
1977\end{array}$ & \\
\hline 94. PL $95-456$ & 5.2249 & $\begin{array}{l}\text { To Prohibit Rate Discrimination In Rates } \\
\text { Charged by the Southwestern Power } \\
\text { Administration }\end{array}$ & \\
\hline 95. PL $95-465$ & H.R. 12932 & $\begin{array}{l}\text { Interior and Related Agencies Appropriations } \\
\text { Act for FY79 }\end{array}$ & \\
\hline 96. PL 95-474 & S. 682 & Tanker Safety Act & \\
\hline 97. PL $95-482$ & H.J.Res. 1139 & $\begin{array}{l}\text { Continuing Appropriations (includes H.R. } 12928 \text {, } \\
\text { Pubiic Workd for Water and Power Development } \\
\text { and Energy Research Appropriations Act of } \\
\text { 1979) }\end{array}$ & \\
\hline 98. PL $95-509$ & H.R. 11686 & $\begin{array}{l}\text { DOE National Security and Military Applica- } \\
\text { tions of Nuclear Energy Authorization Act of } \\
1979\end{array}$ & \\
\hline 99. PL 95-554 & 5.3189 & $\begin{array}{l}\text { Mineral Leasing Act of } 1920 \text {, Amendment Coal } \\
\text { Lease Authorization }\end{array}$ & \\
\hline 100. PL 95-577 & H.R. 13597 & $\begin{array}{l}\text { Rayburn Office Building and House Annex } 2 \\
\text { Solar Collector Installation }\end{array}$ & \\
\hline 101. PL $95-590$ & H.R. 12874 & $\begin{array}{l}\text { Solar Photovoltaic Energy Research Development } \\
\text { and Demonstration Act of } 1978\end{array}$ & $x$ \\
\hline 102. PL $95-604$ & H.R. 13650 & $\begin{array}{l}\text { Uranium Mill Tailings Radiation Control Act of } \\
1978\end{array}$ & \\
\hline
\end{tabular}




\section{ENERGY-RELATED PUBLIC LAWS ENACTED}

FROM THE 91st TO THE 95th CONGRESS

\begin{tabular}{|c|c|c|}
\hline $\begin{array}{l}\text { Legisiative } \\
\text { Basis } \\
\end{array}$ & Name & $\begin{array}{c}\text { CS } \\
\text { Reiated } \\
(x) \\
\end{array}$ \\
\hline H.R. 4018 & $\begin{array}{l}\text { Public Utility Regulatory Policies Act of } \\
1978\end{array}$ & \\
\hline H.R. 5263 & Energy Tax Act of 1978 & $x$ \\
\hline H.R.5037 & National Energy Conservation Policy Act & $x$ \\
\hline H.R. 5146 & $\begin{array}{l}\text { Powerplant and Industrial Fuel Use Act of } \\
1978\end{array}$ & \\
\hline H.R. 5289 & Natural Gas Policy Act of 1978 & \\
\hline
\end{tabular}

\section{4}




\section{DISTRIBUTION}

No. of

Copies

OFFSITE

1 A. A. Churm

DOE Chicago Patent Group

9800 South Cass Ave.

Argonne, IL 60439

20 Jim Eberhardt

Office of Conservation and Solar Applications

27 DOE Technical Information Center

\section{ONSITE}

1 DOE Richland Operations Office

41 Battelle-Northwest

D. E. Deonigi (1)

T. L. Willke (1)

T. J. Foley (1)

R. G. Rivera (15)

A. L. Nieves (15)

Economics Library (1)

Technical Information Files (5)

Publishing Coordination (2) 